\title{
CONSIDERATIONS OF FAIRNESS IN THE CONTEXT OF INTERNATIONAL COMMERCIAL ARBITRATIONS
}

\author{
E.D.D. TAVENDER, Q.C.
}

This article addresses the contrast between the procedural fairness protections that are built into common law judicial practice and the lack of such safeguards in international commercial arbitration. Canvassing a variety of jurisdictions and international arbitration rules, the author concludes that procedural rights in international arbitration are never guaranteed and are at best extremely variable. The solution to such systemic problems is to write procedural requirements into any international commercial agreement so that in the event of a dispute there is some consensus about how the arbitration will be conducted.

Schedule $I$ is a table that explains the general operation of the various statutory instruments that regulate international commercial arbitration. Schedule II is an example of the type of drafted provisions that two private parties might consider grafting onto an international commercial agreement.

\section{TABLE OF CONTENTS}

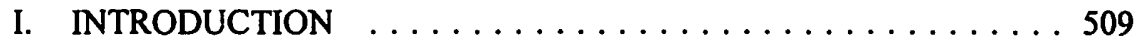

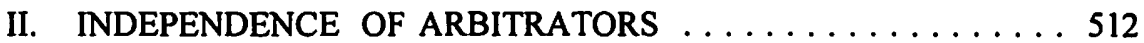

III. EQUALITY AND OPPORTUNITY TO BE HEARD $\ldots \ldots \ldots 515$

A. THE VARIOUS INTERNATIONAL RULES $\ldots \ldots \ldots \ldots 515$

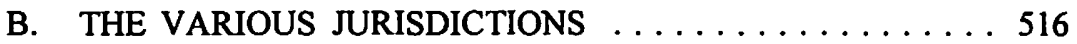

C. ADVERSARIAL AND INQUISITORIAL SYSTEMS $\ldots \ldots 517$

IV. EVIDENCE GATHERING AND DISCOVERY $\ldots \ldots \ldots \ldots .518$

A. DISCOVERY RIGHTS IN THE COURTS ......... 518

B. DISCOVERY RIGHTS IN ARBITRATION ........ 519

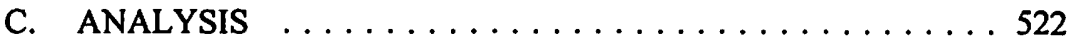

V. PROCEDURAL AND SUPPORTIVE RULES $\ldots \ldots \ldots \ldots \ldots 22$

A. SUPPORTIVE ORDERS AND SANCTIONS GRANTED BY COURTS IN THE ARBITRATION PROCESS ...... 522

B. RULES OF PROCEDURE AND THE

ARBITRATION PROCESS . . . . . . . . . . . . . . 524

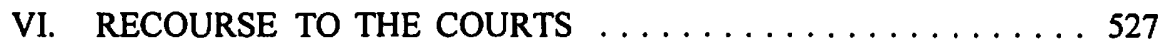

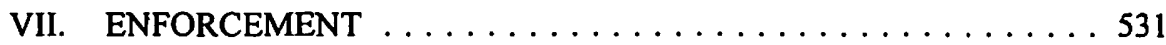

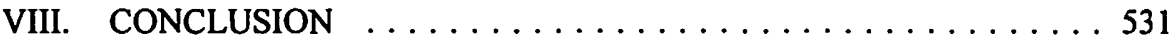

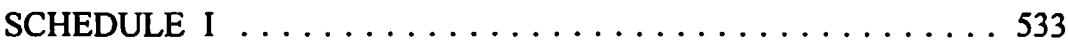

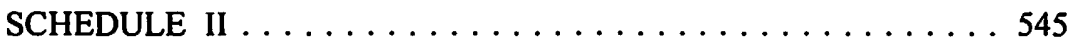

\section{INTRODUCTION}

Fairness is at once an attribute and an aim of our common law judicial system. In this context I use fairness in its broadest sense. It includes the rules and procedures built up over centuries which govern the way in which cases are to be conducted. It includes the substantive results which the courts seek to attain. It includes the right to

E.D.D. Tavender, Q.C. is a partner of the law firm of Milner Fenerty of Calgary and Edmonton. The author would like to acknowledge the assistance of M.A. Hurst, his partner, and Susan M. Wakil and Tania H. Donnelly, both of the Milner Fenerty firm. 
be heard by an unbiased, independent, legally trained court. It includes the right to know in advance the adversary's case that must be met. It includes the knowledge that the decision rendered will be based only on the evidence and arguments presented in court. It includes the right to a reasoned decision publicly rendered in accordance with the rule of law and the principles of stare decisis. It includes the right to correction of errors through appeal. It includes the delivery of decisions that are final, binding and enforceable. Fairness seeks to approximate justice between the parties, based on the pursuit of truth and a correct result. Ultimately it is this fairness that imbues the judicial system with its moral force and acceptability in civilized society. No one could put it more eloquently than Lord Denning:

"If justice had a voice, she would speak like an English judge." No greater compliment has ever been paid to the judges of England. Yet the only quality which the judges have to merit this tribute is that they, each and everyone of them, seek to be fair. Every judge in England will see to it that every man coming before him has a fair trial. To this end there are many principles. ${ }^{1}$

Of course, the pursuit of fairness in the judicial system has not come without a cost. Extensive pre-trial discovery rights, control by the parties and their lawyers over the scheduling of litigation, the right within broad limits to lead any evidence that is even remotely relevant and the conduct of extensive cross-examinations with minimal judicial control have led to criticisms of delay and high cost associated with litigation. When litigation takes on international aspects it suffers further complexities, including a variety of competing and sometimes conflicting jurisdictions, laws, cultures and languages; it forces parties to submit to the decision making power of a foreign and potentially biased court. ${ }^{2}$ In the interests of reducing costs, delay and bias, as well as providing private, flexible resolution of disputes by tribunals selected by the parties and under rules which the parties have a power to control, international commercial disputes have increasingly been referred to arbitration rather than litigation.

It is not the purpose of this article to debate the relative merits of arbitration and litigation, ${ }^{3}$ but rather to investigate the extent to which the principles of fairness

I A.T. Denning, The Road to Justice (London: Stevens and Sons, 1955) at 10.

2 A. Redfern \& M. Hunter, Law and Practice of International Commercial Arbitration, 2d ed. (London: Sweet and Maxwell, 1991) at 25-26.

3 For a discussion of the advantages and disadvantages of international arbitration see ibid. at 22-26; D.L. Zicherman, "The Use of Pre-judgement Attachments and Temporary Injunctions in International Commercial Arbitrations: A Comparative Analysis of the British and American Approaches" (1989) 50 Pittsb. L. Rev. 667; S. Perloff, "The Ties that Bind: The Limits of Autonomy and Uniformity in International Commercial Arbitration" (1992) 13 Penn. J. Int. Bus. Law 323. It is worth noting that the perceived savings in speed, efficiency and cost in international arbitration have not gone unchallenged. In Price v. Milner, [1966] 1 W.L.R. 1235 at 1236 (Q.B.D.), Edmund Davies J., in referring to "disastrous" arbitration proceedings which took five years to produce an award on straight-forward issues in a building contract dispute involving less

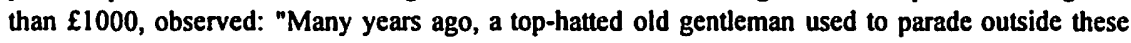
Law Courts carrying a placard which bore the stirring injunction 'Arbitrate - don't litigate!' I wonder whether the ardour of that old gentleman would not have been dampened somewhat had he survived long enough to learn something about the present case." Lord Justice Kerr has discussed some of the disadvantages of international arbitration over litigation and has detailed 
inherent in the common law judicial system are protected in international commercial arbitration. The conclusions, based on a review of legislation, international commercial arbitration rules ${ }^{4}$ and some of the relevant literature, are these:

(a) There are limited and varying protections of faimess in different jurisdictions but none approaching the protection of fairness afforded under the common law judicial system.

(b) Achieving fairness will in large measure be dependent upon the discretion and judgment of individual arbitral tribunals and the agreement of the parties to arbitration.

(c) Only in restricted and varying circumstances will the courts impose principles of fairness upon an arbitral tribunal.

(d) Where principles of fairness are important to parties involved in an international dispute, consideration should be given to refer the dispute to a competent court or to draft appropriate rules and procedures in anticipation of arbitration.

Tailoring special arbitration clauses to address the extent of fairness required in a given case or commercial relationship has special appeal. It helps parties strike a balance between the benefits of arbitration and the objectives of fairness obtainable through litigation. One author cites Russell in The Law of Arbitration as saying:

[T] here is a never-ending war between two irreconcilable principles, a high principle which demands justice though the heavens fall, and the low principle which demands that there shall be an end to litigation. $^{\text {s }}$

several arbitrations which are horror stories in terms of delay and cost: see Lord Justice Kerr, "International Arbitration v. Litigation" (1980) J. Bus. L. 164 and M. Kerr, "Arbitration v. Litigation: The Macao Sardine Case" (April 1987) Int. Bus. Law. 152. See also P.A.C. Jaffe, "The Judicial Trend Towards Finality of Commercial Arbitral Awards in England" (1989) 24 Tex. Int'I L.J. 67 at 82, 105n; F.J. Higgins, W.G. Brown \& P.J. Roach, "Pitfalls in International Commercial Arbitration" (1980) 35 Bus. Lawyer 1035 at 1041-43.

The legislation examined includes Arbitration Act, S.A. 1991, c. A.43.1; Alberta International Commercial Arbitration Act, S.A. 1986, c. I-6.6 [hereinafter AICAA]; and the English Arbitration Act (U.K.), 1950, c. 27 as amended. The international commercial arbitration rules examined are the United Nations Commission on International Trade Law Arbitration Rules [hereinafter UNCITRAL Arbitration Rules], United Nations Commission on International Trade Law Model Law on International Commercial Arbitration [hereinafter UNCITRAL Model Law] which is reproduced in the AICAA as Schedule II; the International Chamber of Commerce Rules [hereinafter ICC Rules]; the American Arbitration Association International Rules [hereinafter AAA Rules]; London Court of International Arbitration Rules [hereinafter LCIA Rules]; International Bar Association Supplementary Rules [hereinafter IBA Supplementary Rules]; CPR Institute for Dispute Resolution Model ADR Procedure [hereinafter CPR Model ADR Procedure]; and British Columbia International Commercial Arbitration Centre Rules [hereinafter BCICAC Rules]. A comparative chart of these Rules is attached as a schedule to this article. 
There is indeed a tension or "never-ending battle" between the interests of justice or fairness on the one hand and finality and efficiency on the other. The purpose of this article is to ensure that the interests of faimess will not be unwittingly overlooked in international commercial arbitrations.

\section{INDEPENDENCE OF ARBITRATORS}

"It is fundamental that an arbitrator must be and remain impartial and independent." ${ }^{6}$ Independence and impartiality on the part of arbitrators are universal requirements. ${ }^{7}$ Persons approached to act as arbitrators are obliged to disclose, in the language of the $A I C A A$, "any circumstances likely to give rise to justifiable doubts as to their impartiality or independence." ${ }^{18}$ This is an on-going obligation. Challenges to the appointment of an arbitrator must be made on a timely basis or will be deemed to have been waived.

With rules requiring impartiality and independence it might be asked why this subject matter is being discussed in the context of fairness. The answer is that there are varying degrees of impartiality and independence in international arbitrations and that in some circumstances those degrees will fall well short of the high standards of impartiality and independence required of the judiciary.

Judges are appointed in our common law system for the duration of their working lives and cannot be removed except for misconduct. Their salaries are paid by the state, not the parties. Their selection to preside over individual cases is generally independent of the will of the parties. They are legally trained and very quickly become judicially trained and experienced. Judges have a duty to uphold the law and recognize the interests of public policy. Within those confines they will hear and decide the merits of a case on the basis that "the two alternative versions of the truth are fully presented and fully tested." 9 The court hearing the case will be neutral and unbiased and seek to render a decision that is a fair reflection of the evidence and arguments advanced by the parties and is in accordance with law and public policy. A judicial decision should thus be as predictable as the conditions of human frailty and uncertainty permit.

Arbitrators, by contrast, are not as insulated as judges from the interests of the parties, the process or the outcome. In this regard the following points are relevant.

(1) Arbitrators are hired for individual cases by the parties involved, under the auspices of an arbitral institution or, on occasion, by the courts. The

$6 \quad$ Redfern \& Hunter, supra note 2 at 218.

7 See Arbitration Act, supra note 4, s. 11(1); UNCITRAL Model Law, supra note 4, art. 12; ICC Rules, supra note 4, art. 2.7; AAA Rules, supra note 4, art. 7; UNCITRAL Arbitration Rules, supra note 4, art. 6.4; LCIA Rules, supra note 4, art. 3.1; CPR Model ADR Procedure, supra note 4, r. 7.1; BCICAC Rules, supra note 4, s. 11(1)-(3); M. Blessing, "The Major Western and Soviet Arbitration Rules" (1989) 6:3 J. Int'l Arb. 7 at 38-41.

- UNCITRAL Model Law, supra note 4, art. 12(1).

9 M.J. Mustill \& S.C. Boyd, The Law and Practice of Commercial Arbitration in England, $2 \mathrm{~d}$ ed. (London: Butterworths, 1989) at 299. 
arbitrators, so selected, are paid substantial fees by the parties. Under the ICC Rules, arbitral fees are based on a percentage of the amount in issue in the arbitration. Under other rules arbitrators are paid their normal hourly rates or reasonable compensation for their time. By definition, then, the arbitrators have a direct pecuniary interest in the arbitration, although their fees are not influenced by the decision they reach.

(2) There are no common or prescribed education and training requirements for arbitrators. Some arbitrators are selected for their specialized knowledge of the subject matter of a dispute. These people, sometimes technical experts, sometimes people with detailed or inside commercial experience, may not have legal training but are expected to provide their insights and specialized knowledge to assist the parties in reaching decisions. This can extend to occasions where such arbitrators have little or no need to call witnesses or consider the conflicting views of experts. ${ }^{10}$ This can give rise to fairness problems since the parties will no longer be in control of the evidence being tendered. They may find that the award is influenced or indeed decided by the specialized knowledge of the arbitrators in circumstances where the parties may have had little or no opportunity to challenge that evidence. "Legal training even in relatively simple disputes is thought to be of value because "difficult problems of procedure and of conflicts of laws frequently arise" in international commercial arbitrations. ${ }^{12}$ In the absence of minimum rules and standards, Redfern and Hunter urge parties to retain those who are both experienced in the law and have practical experience in arbitration. ${ }^{13}$ Of course, some arbitration agreements impose qualifications or experience requirements on those who may serve as arbitrators, which will then become a controlling factor. ${ }^{14}$

(3) In a number of jurisdictions and in a remarkably large number of cases, ${ }^{15}$ arbitrators are selected on the express or implicit assumption that they are "non-neutral" and will be "predisposed" towards the interests of the party appointing that arbitrator. ${ }^{16}$ Mustill and Boyd report on a system in England of employing two separate arbitrators who each act as advocate for one of the parties in an attempt between them to resolve the dispute. In the event of disagreement the dispute is then referred to an independent umpire. ${ }^{17}$ In trade

Mediterranean and Eastern Export Co. Lid. v. Fortress Fabrics (Manchester) Lid., [1948] 2 All E.R. 186 (K.B.D.) at 188-189.

See J.A. Snider \& C.K. Yates, "Alternative Dispute Resolution: Use and Abuse of Information and Specialized Knowledge" (1995) 33 Alta. L. Rev. 301 at 314-318; Astoria Medical Group v. Health Insurance Plan of Greater New York, 182 N.E. 2d 85 (1962) discussed in D.G. Beerbower, "Practical Aspects of Arbitrating Natural Gas Disputes" Natural Gas (Jan. 1990) 24 at 26. Redfern \& Hunter, supra note 2 at 215.

lbid. at 217.

lbid. at 213; Mustill \& Boyd, supra note 9 at 248.

Mustill \& Boyd, ibid. at 258 state "the number must run to tens of thousands."

Redfem \& Hunter, supra note 2 at 221; Mustill \& Boyd, ibid. at 258; Higgins, Brown, \& Roach, supra note 3 at $1043-44$. 
tribunals, where it is common to utilize a panel of three arbitrators, it is expected that each of the parties will select a non-neutral arbitrator who will serve as a negotiating advocate on behalf of the party appointing that arbitrator. This system is common in the United States in domestic arbitrations ${ }^{18}$ and in Canada in trade union arbitrations.

(4) What constitutes bias or a sufficient lack of independence for arbitrators is not always easy to define. Direct financial or employment connections with one of the parties will generally be grounds for disqualifying an arbitrator. ${ }^{19}$ Mustill and Boyd state, however, "More troublesome are business relationships of an intermittent kind: for example, when the party is a good customer or a regular client of the person nominated." ${ }^{20}$ They cite several English decisions in which the courts refused to interfere with the appointment of arbitrators who were connected with legal firms with a history of performing services for one of the parties. Snider and Yates discuss a number of circumstances in which prior connections of an arbitrator to a party, an industrial sector or interest group may not, depending on the circumstances, provide grounds for challenging the appointment of an arbitrator. ${ }^{21}$

(5) Arguably, perhaps as a consequence of some of the factors listed above, arbitrations may result in compromise decisions. Goldberg, Sander and Rogers state in this regard:

Further, it is charged that some of the purported advantages of arbitration over court adjudication are actually disadvantages. For example, the parties' ability to select the arbitrator is said to encourage arbitrators to search for compromise decisions to avoid antagonizing parties who they hope will select them in future cases. ${ }^{22}$

In result, the high level of impartiality and independence of the courts in the litigation system is not assured in arbitration. This may lead to some arbitral awards appearing to fall short of what is fair and just. The best control over this risk lies in the selection of highly reputable and qualified arbitrators. As Redfern and Hunter state:

The reputation and acceptability of the arbitral process depends on the quality of the arbitrators. The task of presiding over the conduct of an international commercial arbitration is no less skilled from that of driving a car or flying an aircraft. It should not be entrusted to someone with no practical experience of it. ${ }^{23}$

lbid. at 222-23, 251 .

Ibid. at 251 .

Snider \& Yates, supra note 11; see also Beerbower, supra note 11.

S.B. Goldberg, F.E.A. Sander \& N.H. Rogers, Dispute Resolution: Negotiation, Mediation, and Other Processes, 2d ed. (Boston: Little Brown, 1992) at 201. Compare Redfern \& Hunter, supra note 2 at 417 , that there is almost always a "winner" and a "loser" in arbitrations. 


\section{EQUALITY AND OPPORTUNITY TO BE HEARD}

The duty to act judicially is a duty which extends to all aspects of the proceedings. Neither the arbitral tribunal as a whole nor any of its individual members should, for instance, discuss the case with one party in the absence of the other, unless the discussions concern purely procedural matters (of which the other party is then promptly informed), or unless the absent party has failed to attend a meeting or a hearing, having been given proper notice to do so. At the hearing, the duty to act judicially means that each party must be accorded equality of treatment and given an equal opportunity to present his case. It would be wrong, for instance, to allow one party to call witnesses and to deny this right to the other party; similarly, it would be improper to allow one party to address the arbitral tribunal and to deny this right to the other party. ${ }^{24}$

This may assure equality, but how far does the right to be heard extend?

\section{A. THE VARIOUS INTERNATIONAL RULES}

Article 18 of the UNCITRAL Model Law provides, "The parties shall be treated with equality and each party shall be given a full opportunity of presenting his case." Article 24 requires that oral hearings be conducted if requested by a party and that all statements, documents and other information supplied to the arbitral tribunal by one party shall be communicated to the other party. Article 26(2) affords each party the right to put questions to experts and call expert testimony on points at issue.

The International Bar Association Supplementary Rules empower the arbitrator to determine whether oral evidence should be given. ${ }^{25}$ Where oral evidence occurs, a right of cross-examination and re-examination is provided, but the arbitrators have "the right to limit or deny the right of a party to examine, cross-examine or re-examine a Witness when it appears to the Arbitrator that such evidence or examination is unlikely to serve any further relevant purpose." 26 The American Arbitration Association (AAA) Rules and the London Court of International Arbitration (LCIA) Rules permit the arbitrator to deviate from common law procedures in the presentation of evidence, and neither assures a party the right of cross-examination. ${ }^{27}$

The International Chamber of Commerce (ICC) Rules empower the arbitrator "to establish the facts of the case by all appropriate means" with no expressed requirement to provide the parties with a full opportunity to present their cases. The arbitrator may decide to hear the parties or any other party and may appoint one or more experts and hear their evidence. The arbitrator may decide the case on documents alone if the parties request or agree. ${ }^{28}$ The farthest the ICC Rules go in providing parties with the full opportunity to be heard is to require in advance the exchange of written statements

lbid. at 268-269. See also Blessing, supra note 7 at 16, 42.

IBA Supplementary Rules, supra note 4, art. 5.10.

lbid., art. 5.10; see also ibid., art. 5.9.

S.J. Stein \& D.R. Wotman, "International Commercial Arbitration in the 1980's: A Comparison of the Major Arbitral Systems and Rules" (1983) 38 Bus. Law. 1685 at 1715-16.

ICC Rules, supra note 4, art. 14. 
of each side's case supported by the documentation or information relied on "to establish the circumstances of the case," ${ }^{\prime 29}$ and to give parties the right to request the arbitrator to "hear the parties together in person. ${ }^{130}$ Commentators have accordingly interpreted the ICC Rules (and to a lesser extent the UNCITRAL Rules) as embodying the continental civil law inquisitorial system which may be incompatible with common law concepts of a full right to be heard. ${ }^{31}$ It should be noted that neither the ICC nor the UNCITRAL Model Law Rules expressly authorize cross-examination. ${ }^{32}$

\section{B. THE VARIOUS JURISDICTIONS}

In civil law systems, the focus is upon the arbitrators themselves, who have discretion to order factual investigations or appoint experts to compile reports as they see fit. ${ }^{33}$ Generally, the arbitrators will question the witnesses on matters which remain unclear, thereby reducing the need for long and drawn-out oral examinations by counsel. Redfern and Hunter state that in international arbitrations, the arbitrator's motivation is to shorten the duration of the oral stage of the proceedings. ${ }^{34}$ This objective is not achieved if either the tribunal or the parties subject witnesses to lengthy oral examination.

In England, the Arbitration Act of 1950 ensures that the fundamental rules of natural justice will be imposed generally and enforced. Russell states that an arbitrator "gives a decision in accordance with his duty to hold the scales fairly between the disputants in accordance with some recognized system of law and the rules of natural justice. ${ }^{.35}$ A failure to observe the rules of natural justice may provide a basis for challenging an award on the ground of an error of law or misconduct for which judicial review is permitted under current English law. ${ }^{36}$

In the U.S.A. full rights to be heard, including the right of cross-examination, are considered to be an essential element of a fair hearing in an arbitration. ${ }^{37}$ Whether and under what circumstances a failure to afford full rights of cross-examination will constitute grounds for judicial interference in other than extreme circumstances is less

Ibid., art. 3.

Ibid., art. 14.

Blessing, supra note 7 at 52-53; Stein \& Wotman, supra note 27 at 1715. Similar concerns arise out of restrictions on the right to challenge facts and expertise relied on by an arbitrator selected with "specialized knowledge" as discussed above.

See generally Redfern \& Hunter, supra note 2 at 349; Higgins, Brown \& Roach, supra note 3 at 1047; W.G.O. Morgan, "Discovery and Arbitration" (1986) 3:1 J. Int'l Arb. 9 at 20-25.

Stein \& Wotman, supra note 27 at 1707.

Redfern \& Hunter, supra note 2.

A. Walton \& M. Vitoria, Russell on the Law of Arbitration, 20th ed. (London: Stevens \& Sons, 1982) at 104.

Ibid. at 214, 218-19. But see the restrictions on appeal rights in England discussed below in Part VI "Recourse to the Courts."

Stein \& Wotman, supra note 27 at 1716. 
than clear $^{38}$ One commentator summarized the U.S. position this way: "The arbitrator's decision may be completely contrary to law and yet the decision will stand, with our courts having very restricted powers to set the award aside. ${ }^{139}$

Judicial reluctance to intervene in arbitration proceedings is not confined to the United States. As discussed under Part V, below, there is a trend especially evident in international commercial arbitrations that the parties, having selected arbitration in preference to the courts, should be prepared to abide by the results of arbitration, good or bad.

\section{ADVERSARIAL AND INQUISITORIAL SYSTEMS}

What emerges from this discussion is that the extent of a party's opportunity to be heard will vary from jurisdiction to jurisdiction with uncertainty that the courts (except perhaps in England) will intervene other than in the clearest, most egregious circumstances. This could have serious repercussions in complex cases involving issues of credibility and disagreements over material facts and expert opinion. How, one might ask, can a credibility issue or a serious disagreement over expert opinions be resolved by arbitrators restricting themselves to reading pre-digested adversarial written statements of positions? Lawyers steeped in the adversarial tradition of the common law would answer "never," at least if a decision approximating justice between the parties is the objective. Common law lawyers would expect, indeed demand, the right to lead relevant evidence and conduct pointed and sometimes searching cross-examinations in order to assist a tribunal in getting close to the truth. That speaks for the broadest opportunity for a party to present its case including, where appropriate, the right of cross-examination. Continental lawyers, by contrast, might well have more confidence that an inquisitorial arbitrator, trained in the civil law, would effectively achieve justice by conducting on behalf of the parties the investigation and challenging of all relevant evidence. However, international arbitration rules fall short of imposing that sort of obligation on arbitral tribunals.

One should not pass by the continental system without acknowledging some of its strengths. Lord Justice Kerr cautioned common law lawyers not "to be dominated by English procedures":

In long and complex cases the Continental inquisitorial procedure is often more effective than our adversary system. It is often better for the tribunal to limit discovery in the first instance, to appoint its own experts, and then to exercise control over the volume of discovery and the witnesses whom Wotman, supra note 27 at 1716; contra J.B. Casey, International and Domestic Commercial Arbitration (looseleaf) (Scarborough: Carswell, 1993) at para. 7.17(d) who suggests denial of right to cross-examination where credibility is in issue may be reviewable in Canada. 
it wants to hear. Our arbitrators will have to learn to be more imaginative than merely to follow the mirror-image of the procedure in our courts. ${ }^{40}$

One might add that recent experience in common law jurisdictions with case management and court-annexed mediation is directly responsive to concerns of this sort. Case management employs active intervention and control by the courts over the time and steps required to get a case to and through trial. It is expected to produce substantial reductions in the delays and costs associated with traditional litigation. It hints at combining some of the better elements of both the common law and continental systems. ${ }^{41}$

What is important to draw out of this discussion are these points:

(1) In the various international commercial arbitration rules there is an underlying conflict between the common law and continental systems.

(2) There are no assurances under many of the rules that parties will be assured either of the broadest opportunity to be heard or that the arbitral tribunal will carry out the full rigours of the inquisitorial system in order to assure that justice will be done between the parties.

(3) The rules in the various jurisdictions relating to the opportunity to be heard and the right to conduct cross-examinations differ quite substantially. The opportunity for judicial intervention is limited.

(4) A healthy dose of preventative draftsmanship in arbitration clauses or submissions to arbitration would accordingly appear to be highly desirable in order to bring a degree of certainty into this difficult area. ${ }^{42}$

\section{EVIDENCE GATHERING AND DISCOVERY}

\section{A. DISCOVERY RIGHTS IN THE COURTS}

Nowhere is the contrast between common law litigation and international arbitration more evident than in respect to discovery rights. Let us set out some basic guidelines dealing first with court systems.

$40 \quad$ Lord Justice Kerr, supra note 3 at 180.

4 For general discussion on case management see: Report of the Independent Working Party set up jointly by the General Council of the Bar and the Law Society, Civil Justice on Trial - The Case for Change (June 1993) (Chair: Hilary Heilbron, Q.C.) [hereinafter the Heilbron Report]; The Hon. R.A. Blair et al., "Civil Justice Review" First Report of the Ontario Court of Justice and Ontario Ministry of the Attorney General (March 1995); Lord Taylor of Gosforth, "Civil Litigation: Case Management, Practice Direction of English High Court" (January 24, 1995).

42 S. Houck, "Complex Commercial Arbitration: Designing a Process to Suit the Case" in Goldberg, Sander \& Rogers, supra note 22 at 207. 
(1) In continental legal systems there are no procedures akin to common law discovery rights. ${ }^{43}$

(2) In England the pre-trial gathering of evidence consists of production and inspection of all relevant documents, responses under oath to written interrogatories and the exchange before trial of proposed witnesses' statements. ${ }^{44}$ Oral examinations for discovery are not available in England except with the leave of the court. ${ }^{45}$ Expert reports must be simultaneously exchanged before trial and will be ordered by the court unless there are special reasons for not doing so. The overriding consideration is "to maintain fairness and mutuality between the parties." 46

(3) In Canada there are pre-trial discoveries of documents and oral examinations for discovery of parties. Variations in the extent of oral discoveries exist in different provinces. ${ }^{47}$ Expert reports must generally be exchanged prior to the trial.

(4) In the United States the Federal Rules of Civil Procedure provide for the broadest of pre-trial discovery rights. These rights include mandatory disclosure of documents and potential witnesses possessing relevant discoverable information, the disclosure of insurance available to satisfy a judgment, oral discoveries extending to non-parties and experts, and pre-trial disclosure of written reports of experts. ${ }^{48}$

\section{B. DISCOVERY RIGHTS IN ARBITRATION}

Now, let us examine arbitration guidelines relating to discovery.

(1) In England prior to 1990, the Arbitration Act empowered the courts to order discovery in accordance with English procedures. This provision has since been repealed. ${ }^{49}$ Mustill and Boyd imply that arbitrators in England have a

4) Morgan, supra note 32 at 20-21.

44 Halsbury's Laws of England, 4th ed. (London: Butterworths, 1976) at vol. 13 "Discovery," vol. 37 "Practice and Procedure" paras. 310-11 [hereinafter Halsbury's]; The Supreme Court Practice (1995) vol. 1 (London: Sweet \& Maxwell, 1994) 0. 24, O. 26.

Halsbury's, ibid. vol. 13, "Discovery, Inspection and Interrogatories" at para. 100; Heilbron Report, supra note 41 at 50-51.

46 The Supreme Court Practice, supra note 44 at paras. 38/35/1, 38/35/12.

47 For example, in Nova Scotia third parties may be discovered: D.S. Ehrlich, Nova Scotia Annotated Rules of Practice (1994), r. 18. In Alberta, employees of a corporation may be discovered: Alberta Rules of Court, r. 200. In Ontario, the discovery of a corporation is limited to the corporate officer: J.J. Carthy et al., The Ontario Annual Practice 1994-95 (Aurora: Canada Law Book, 1994), r. 31.03(2).

49 Arbitration Act, (U.K.), supra note 4, s. 12(6)(b), as rep. by the Courts and Legal Services Act (U.K.), 1990, c. 41, s. 103. See Morgan, supra note 32 at 12-14, where the author suggests that even prior to 1990, courts would not review an arbitrator's refusal to order discovery. See also Perloff, supra note 3 at 348; Stein \& Wotman, supra note 27 at 1706. 
discretion to order varying degrees of discovery, or none at all, depending on the circumstances. ${ }^{50}$ Redfern and Hunter cite the repeal of s. 12(6)(b) of the 1950 Arbitration Act as an example of "an increasing trend for courts to leave arbitral tribunals to their own devices in international cases." ${ }^{51}$

(2) In the U.S.A. it is perhaps still unresolved as to whether and under what circumstances the courts will intervene in an arbitration where discovery rights have been denied. It is theoretically arguable that the failure to allow discovery rights where a party can show prejudice would constitute misconduct or a violation of public policy or the due process provisions of the American Constitution. Commentators do not give strong support for this proposition although Tupman, citing a New York decision, does suggest that the point is arguable:

This is not to say that the principle of fundamental fairness which underlies federal discovery rules might not be successfully invoked in certain circumstances. "The absence of statutory provision for discovery techniques in arbitration proceedings obviously does not negate the affirmative duty of arbitrators to insure that relevant documentary evidence in the hands of one party is fully and timely available to the other side before the hearing is closed" ... [T] he decision not to allow discovery might constitute a ground for refusing to enforce a foreign arbitral award if a party were 'unable to present his case' as a result, or if enforcement would be contrary to the 'public policy' of the United States.'

(3) Some of the most important arbitration rules (UNCITRAL Model Law and ICC) are silent on the power to order production of documents. ${ }^{53}$

(4) Most arbitral tribunals tend only to grant requests to produce specified documents as opposed to responding to a broad request for production of all relevant documents. ${ }^{54}$

Supra note 9 at 325-26.

Supra note 2 at 310.

Tupman, supra note 38 at 32. See Morgan, supra note 32 at 15-18, 20; Perloff, supra note 3 at 346; L.H. Willenken, "Discovery in Aid of Arbitration" (1980) 6:2 Litig. 16; Goldberg, Sander \& Rogers, supra note 22 at 215-216. Generally, American courts will not order discovery unless the evidence is necessary and "extraordinary circumstances" exist: S. Cohen, "International Commercial Arbitration: A Comparative Analysis of the United States System and the UNCITRAL Model Law" (1996) XII:3 Brooklyn J. Int'l L. 703 at 717.

See AAA Rules, supra note 4, art. 3.1. This rule allows the arbitrator to request the parties to produce such additional evidence as the arbitrator deems necessary to understand and determine the dispute: Blessing, supra note 7. Of similar effect is art. 24(3) of the UNCITRAL Arbitration Rules, supra note 4. Note that the U.S. Federal Rules of Civil Procedure purport to apply to arbitrations even though the courts seem not to have exercised that power: Perloff, supra note 3 at 346, Tupman, ibid., Blessing, ibid. at 21-22 and 52-53.

Tupman, ibid. 
Criticisms of excessive discoveries abound in the literature, but few deny the valuable contribution effective discovery can make in pursuit of fairness. The following quotations may help to put discovery in perspective:

Discovery is an essential feature of the English adversary system. Properly used, it is a powerful instrument of justice. In cases where all the information as to a particular event or fact lies in the hands of one party, discovery may provide the only means of ascertaining the truth.

On the other hand, if it is employed without discrimination, the procedure can have serious practical disadvantages. In complex cases, a full order for discovery may require the parties to list and produce large quantities of documents, all but a small fraction of which are of no interest or value to either party...

Moreover, the making of an order for discovery takes for granted that both sides will thoroughly comply with the order. If this assumption is falsified, and one party gives full discovery while the other does not, the former may be placed at a serious disadvantage ... Many foreigners view with incredulity a system which requires them to procure (for example) documents passing within their own organization, which were never intended for general distribution...ss

Whether arbitration is in other respects more or less costly than court adjudication may well depend in part upon the extent to which in a particular case the arbitral tribunal permits discovery procedures comparable to those which have made American litigation so costly and which have been the subject of much critical comment. Of course, cost savings achieved by reducing or eliminating discovery will be little appreciated by the party whose case may depend on documents which can be obtained only through discovery. ${ }^{\text {so }}$

The primary purpose of modern discovery procedures is to enable the litigants to obtain a more informed picture of the facts of the case more quickly and at less expense than they could by relying on their own unaided initiative. The basic premise of modern discovery, then, is that fuller disclosure, which may ultimately entail forced disclosure, will permit each party to present the most complete and favourable case that can be made on his behalf at trial, and will minimize the possibility that ignorance of relevant facts, or the adversary's sudden presentation of unanticipated evidence, will obscure the true state of affairs out of which the controversy arose.... [Discoveries] cause disclosure of relevant information before trial in order to render the judicial process more accurate and fair. ${ }^{57}$

Broad discovery is somewhat unusual for an arbitration, but it provided both sides with a full and fair opportunity to develop the facts, eliminated surprise at the hearing, and considerably expedited the hearing itself. The availability of discovery was essential to the perception that the process would eventuate in a just result. Indeed, discovery was a sine qua non to the arbitration itself involving as 
it did allegations of conspiracy and willful infringement that would be almost impossible to prove without access to the other side's documents. ${ }^{38}$

\section{ANALYSIS}

From this discussion it must be evident that in most, if not all, jurisdictions, no party can be assured of significant rights of pre-hearing discovery. It should further be obvious that broad, unrestricted use of discoveries in arbitration proceedings could mimick that which is thought to contribute to excessive cost and delay in judicial proceedings. In relatively simple, or primarily documentary, disputes, discovery may be of little or no value and could quite properly be excluded in international arbitrations. In more complex and substantial matters, where, for example, credibility is in issue, where essential facts and opinions are in conflict, where one party only is in possession of key information or where important oral evidence will be tendered, discovery rights may be seen to be essential in the pursuit of fairness and a just result.

Parties entering into international transactions would be well advised to assess the potential range of disputes that might later arise before settling on a standard arbitration clause. The tailoring of a more detailed arbitration clause that provides some certainty to discovery rights could usefully be negotiated. Failing that, consideration could be given to referring substantial disputes to a respected court rather than run the risks of later arguing over the nature and extent of discoveries or, worse, being subjected to an arbitration in which essential discovery rights are denied.

\section{PROCEDURAL AND SUPPORTIVE RULES}

Apart from equality and the arguable extent of the opportunity to be heard, the standard rules of practice and procedure that govern litigation will not be applied to arbitral tribunals. ${ }^{59}$ The only exception to this principle is what may be called supportive orders and sanctions that courts may grant in certain circumstances to give efficacy to the arbitration process.

\section{A. SUPPORTIVE ORDERS AND SANCTIONS GRANTED BY COURTS IN THE ARBITRATION PROCESS}

In a number of jurisdictions arbitration rules empower courts to grant interim measures. ${ }^{60}$ The Alberta Arbitration Act has such a provision. Section 8(1) provides: "The court's powers with respect to the detention, preservation and inspection of property, interim injunctions and the appointment of receivers are the same in arbitrations as in court actions." The wording of the Alberta International Commercial Arbitration Act is significantly different and less explicit. That $A c t$, by incorporating the

\section{S. Houck, supra note 42 at 209.}

Morgan, supra note 32 at 12-13, 17-18; Perloff, supra note 3; S. Hepburn, "Natural Justice in Commercial Arbitration" (1993) 21 Austl. Bus. L. Rev. 43 at 49-51. See Mustill \& Boyd, supra note 9 at 17-18.

Blessing, supra note 7 at 23. 
UNCITRAL Model Law, empowers the arbitral tribunal to "order any party to take such interim measure of protection as the arbitral tribunal may consider necessary in respect of the subject-matter of the dispute" and may require "any party to provide appropriate security."61 Article 9 adds, "It is not incompatible with an arbitration agreement for a party to request, before or during arbitral proceedings, from a court an interim measure of protection and for a court to grant such measure."

The English Arbitration $A c t^{62}$ empowers the High Court to grant interim injunctions, and this power has been broadly construed to include the power to detain or preserve goods, preserve the status quo, grant Mareva injunctions, appoint receivers, order the continued performance of contracts during arbitration and grant security for costs. $^{63}$ Generally the English courts will restrict these types of interim orders to parties who are properly before the jurisdiction of the English courts, ${ }^{64}$ but in "exceptional cases" the English courts may extend their protective measures (for example by granting security for costs) where the only connection with England is the fact that the arbitration takes place there. ${ }^{65}$

The ICC Rules provide that before a file is transmitted to the arbitrator and "in exceptional circumstances even thereafter" the parties may apply to the courts "for interim or conservatory measures. ${ }^{106}$

Article 22 of the AAA International Arbitration Rules empowers the arbitration tribunal to order "interim measures" including measures for the conservation of the goods in question. Further, the tribunal may require security for costs and, as in the UNCITRAL Arbitration Rules, a request to a judicial authority for interim measures "shall not be deemed incompatible with the agreement to arbitrate. ${ }^{167}$

Commentaries suggest that there is uncertainty as to how the courts in the U.S. will respond to requests to impose interim measures on parties to arbitrations. ${ }^{68}$ Hoellering, while stating that the courts will react to applications relating to interim measures on a "case-by-case basis"69 and that guidance from the U.S. Supreme Court is required, ${ }^{70}$

UNCITRAL Model Law, supra note 4, art. 17.

Supra note 4, s. 12(6).

J. Hill, "The Jurisdiction of the Courts to Grant Interim Measures in Support of Arbitration Proceedings" (Aug. 1992) Lloyds Mar. \& Cm. L.Q. 310; N.H. Andrews, "Arbitration Under ICC Rules and Security for Costs" (1994) Cambridge L.J. 470; B.W. Shenton, "Attachments and Other Interim Court Remedies in Support of Arbitration" (1984) 12 Int'l Bus. Lawyer 101; Mustill \& Boyd, supra note 9 at $328-43$.

Channel Tunnel Group Lid. v. Balfour Beatty Const. Ltd., [1992] 2 W.L.R. 741 (C.A.).

S.A. Coppée Lavalin N.V. v. Ken-Ren Chemicals \& Fertilizers Ltd., [1994] 2 W.L.R. 631 (H.L.); see case comment by Andrews, supra note 63 and S. Nappert, "The House of Lords on Security for Costs and ICC Arbitration: Coppée-Lavalin S.A.IN.V. v. Ken-Ren Chemicals and Fertilizers Limited" (1994) 73 Can. Bar. Rev. 582.

ICC Rules, supra note 4, art. 8(4).

UNCITRAL Arbitration Rules, supra note 4, art. 26.3.

M.F. Hoellering, "Interim Measures in Arbitration: The Situation in the United States" (1991) 46:2

Arb. J. 22; Stein \& Wotman, supra note 27 at 1689-90, 1708-09.

Hoellering, ibid. at 24. 
suggests that the U.S. courts have generally recognized the desirability of limited judicial intervention in order to encourage the use of arbitration. ${ }^{n}$

There is authority to support the proposition that arbitrators in some jurisdictions may have powers to grant interim orders securing the amount of the claim in advance of the hearing. This would go well beyond the powers of common law courts which, except in unusual circumstances, refuse to grant what is in effect execution before judgment. $^{72}$ Mustill and Boyd cite with approval the use of an order nisi by which arbitrators may impose as a condition of obtaining one type of interim relief a condition that the applicant post security for the claim. ${ }^{73}$ In a recent U.S. decision, ${ }^{74}$ an arbitral order requiring the posting of security to cover the claim was overturned by the Massachusetts Supreme Judicial Court on the narrow ground that the AAA Rules governing the arbitration restricted the arbitrator's powers to safe-guarding the property that was the subject matter of the proceedings. Parties interested in this type of extraordinary relief would be well advised to include express powers to this effect in their arbitration agreement.

The common law courts, of course, provide a wide range of procedural rules to assist and support litigation. These include, but go far beyond, the granting of interim protective orders. The Rules of Court in Alberta, for example, contain in excess of 900 separate rules to support and facilitate the conduct of all aspects of court proceedings. These rules include such things as pleadings, parties, consolidation of actions, service of processes within and without the court's jurisdiction, documents, obtaining evidence from third parties, discoveries, expert reports, the conduct of trials and appeals, the granting of extraordinary remedies, costs, sanctions and enforcement of judgments. The statutory and substantive law in the judicial system expands on these rules of procedure and provides guidance as to such diverse things as the admissibility of evidence, the calculation and payment of interest, the production of confidential and privileged information, the kinds of compensation and damages recoverable and the obligation of courts to state reasons for their decisions.

\section{B. RULES OF PROCEDURE AND THE ARBITRATION PROCESS}

It may be arguable in England that the failure of arbitrators to adhere to essential procedural rules created under English law constitutes an error of law which could be reviewable by the courts. In most other international arbitration jurisdictions (and probably in England too) only in the most extraordinary circumstances would courts intervene for a violation of such rules of practice and procedure.

Ibid. at 27; see also D.I. Zicherman, "The Use of Pre-judgment Attachments and Temporary Injunctions in International Commercial Arbitrations: A Comparative Analysis of the British and American Approaches" (1989) 50 Univ. of Pitts. L. Rev. 667.

$"$ Hoellering, ibid. at 23.

72 See Aetna Financial Services v. Feigelman (1985), 15 D.L.R. (4th) 161 (S.C.C.)

$73 \quad$ Mustill \& Boyd, supra note 9 at 343, citing Japan Line Lid. v. Aggeliki Charis, [1980] 1 Lloyd's Rep. 288 (C.A.).

74 Charles Construction Co. Inc. v. Dederian 586 N.E. $2 d 992$ (1992). See also D.L. Evans \& I.R. Good, "Pre-Award Security in Arbitration" (1993) 37 Boston B.J. 19. 
How serious is this? Consider several practical examples.

(1) Two parties to an international arbitration arising out of a contract containing an arbitration clause find that the issues of liability and damages lead to issues that are outside of the scope of the submission to arbitration. ${ }^{75}$ Further, the dispute may give rise to claims against third parties not subject to the agreement to arbitrate. Court procedures dealing with consolidation of actions and third party procedures would permit these matters to be heard and determined at one time by one court. There would appear to be no comparable solution with respect to arbitrations. The jurisdiction of the courts would appear to be limited to staying any judicial proceedings that are the subject matter of an arbitration submission and in consolidating separate arbitration proceedings on the agreement of the parties. ${ }^{76}$ As Lord Justice Kerr stated, "There is no procedure for bringing related disputes under the umbrella of one arbitration; nothing analogous to our third-party procedure." ${ }^{77}$ Mustill and Boyd state that the inability to deal with third party situations is "[o]ne of the weakest features of English arbitral procedure." ${ }^{78}$ In complex arbitrations, significant complications can readily arise because of the arbitrator's limited jurisdiction. This can lead to delays, added cost and the potential for conflicting decisions being reached by separate courts and arbitral tribunals. The drafter of an arbitration clause might well insert a provision terminating arbitration when multi-party problems of this sort arise.

(2) Issues of confidentiality and privilege with respect to documents and communications frequently arise in complex commercial disputes. The courts have developed a set of rules and procedures which ensure the production of relevant, non-privileged information while protecting parties against abuse. It is not uncommon in arbitrations to encounter parties refusing to disclose relevant information on the grounds of confidentiality. For example, a party to a gas pricing arbitration may have confidential contracts with other parties that, if disclosed, would provide good evidence of comparable market prices. What remedy would the party seeking production of that confidential information have if the arbitral tribunal declined to order the production of such confidential information? There is significant risk that the courts might feel powerless to intervene to compel the production of such confidential information or to vacate an arbitral decision based on such a ruling. ${ }^{79}$ With

Mustill \& Boyd, supra note 9 at 6-7 suggest that tort claims closely associated with the subject matter of the contract and issues such as frustration, repudiation and recision may fall within broad arbitration clauses, but that arbitrators cannot have "jurisdiction to decide upon issues which go to the essential validity of the substantive contract: such as, for example, whether it is void for mistake or for lack of consensus or consideration." AICAA, supra note 4 , s. 8.

Lord Justice Kerr, supra note 3 at 176.

Mustill \& Boyd, supra note 9 at 143.

There is a risk that even in a domestic arbitration in Alberta the courts would not intervene in these circumstances. Section $\mathbf{4 4}$ of the Alberta Arbitration Act permits judicial review of arbitration decisions on important questions of law that will significantly affect the rights of the parties, but 
this sort of uncertainty parties might well be advised to cover this point in their arbitration clause.

(3) Another example relates to the presence or absence of reasons supporting an arbitral decision. In the court system reasons are required to support a decision. ${ }^{80}$ Lord Denning said in this regard:

...[I]n order that a trial should be fair, it is necessary, not only that a correct decision should be reached, but also that it should be seen to be based on reasons, and that can only be seen, if the judge himself states his reasons. Furthermore if his reasons are at fault, then they afford a basis on which a party aggrieved by his decision can appeal to a higher court. ${ }^{81}$

In international arbitrations there is no universal rule that written reasons must be provided. Unless the parties have agreed otherwise, the UNCITRAL Model Law, ${ }^{82}$ LCIA, ${ }^{83}$ the AAA Rules, ${ }^{84}$ the CPR Model ADR Procedure, ${ }^{85}$ and the BCICAC Rules ${ }^{86}$ require reasons. The ICC Rules may arguably by implication require reasons since art. 21 requires that the "draft award" be submitted to the ICC Court of Arbitration for scrutiny and modifications. In the United States, however, reasons, according to the literature, ${ }^{87}$ are often not issued. $^{88}$ If judicial review of an arbitration decision is not desired or permitted and arbitrators are paid on the basis of their time, it is perhaps hard to understand why parties would encourage the delivery of reasons in support of an arbitration decision. On the other hand, a costly arbitration involving complex issues that produces a mere "yes" or "no" or a mere number representing the amount of money to be paid would seldom satisfy a losing party that a just and correct decision had been reached.

(4) The courts award compensation and damages in accordance with well known legal principles. Would it be open, for example, for an arbitral tribunal to

s. 44(3) contains an exception to those appeal rights. Section 44(3) states that "a party may not appeal an award to the court on a question of law which the parties expressly referred to the arbitral tribunal for decision." Recent case law in Alberta has left unanswered the question of whether a procedural ruling by an arbitral tribunal would be caught by s. 44(3): Pachanga Energy Inc. v. Mobil Investments Canada Inc., [1993] 4 W.W.R. 176 at 179, 8 Alta. L.R. (3d) 284 (Q.B.), aff'd (1993), 15 Alta. L.R. (3d) I (C.A.); Canadian Western Natural Gas Company Limited v. Alberla Energy Company Lid. et al. (1995), 28 Alta. L.R. (3d) 257 (Q.B.).

See, e.g. Nova v. Guelph Engineering (1989), 70 Alta. L.R. (2d) 97 (C.A.) at 108-09.

Denning, supra note 1 at 29.

UNCITRAL Model Law, supra note 4, art. 31.

LCIA Rules, supra note 4 , art. 16.

AAA Rules, supra note 4, art. 28(2).

CPR Model ADR Procedure, supra note 4, r. 14.2.

BCICAC Rules, supra note 4, s. 34(4).

Goldberg, Sander \& Rogers, supra note 22 at 217.

Ibid:; Stein \& Wotman, supra note 27 at 1719: "An award without an opinion is less subject to challenge in those jurisdictions where arbitrators are not required to give reasons for their award. The policy reason against reasoned awards is frankly to discourage the losing party from appealing." 
award punitive or exemplary damages in a case where intentional, malicious or fraudulent activities have been established, and, whatever the decision, would that be reviewable by the courts? Except for England (where errors of law are reviewable) the answer is doubtful. In a recent decision of the U.S. Supreme Court, ${ }^{89}$ an arbitration award of punitive damages was affirmed even in circumstances where the parties to the arbitration had agreed to be governed by the law of New York which prohibited arbitrators from awarding punitive damages.

(5) As a final example, let us address the common problem raised in arbitration hearings of the admission of hearsay evidence. It is clear that in common law courts hearsay is generally not admissible because its truth cannot be challenged under cross-examination in the courtroom. It is equally clear that in international commercial arbitrations (and indeed in domestic arbitrations) arbitral tribunals are free to "determine the admissibility, relevance, materiality and weight of any evidence." ${ }^{100}$ The Alberta Arbitration Act goes even further and provides that an arbitral tribunal "is not bound by the rules of evidence or any other law applicable to judicial proceedings." ${ }^{\text {91 }}$ In arbitrations it must then be understood that decisions can theoretically be influenced by hearsay assertions not capable of being challenged or questioned. This led Seigel to entitle an article "Roll Over Professor Wigmore, Before Arbitration Does it for You!"'92

Are these problems serious? The answer is that they could be in certain, specific cases. Once again a consideration of these types of concerns strongly supports parties addressing these issues at the time of drafting their arbitration clauses in order to introduce certainty and acceptable standards and procedures.

\section{RECOURSE TO THE COURTS}

While appeal rights are fundamental to ensure the correctness and fairness of court decisions, appeal rights in international arbitrations are circumscribed in varying degrees. This is supported by a trend seen in many jurisdictions that a party, having selected arbitration in preference to the courts, should not be easily able to escape the burden and finality of an unfavourable result. Redfern and Hunter state in this regard:

This is in line with the growing conviction that, so far as international commercial arbitrations are concerned, the parties should be prepared to accept the decision of the arbitral tribunal. If a court is

Mastrobuono v. Shearson Lehman Hutton, 131 L. Ed. 2d 76 [hereinafter Mastrobuono] No. 94-18 (March 6, 1995), discussed in "High Court Rules that choice of law clause can't stop award of Punitives by Arbitrators" (1995) 13 Alternatives to the High Costs of Litigation 59.

See UNCITRAL Model Law, supra note 4, art. 19(2); AAA Rules, supra note 4, art. 21(6); BCICAC Rules, supra note 4, s. 19(3).

Supra note 4, s. 21(1).

Seigel, supra note 39. See also Casey, supra note 38 at para. 7-17(c), who argues that in certain circumstances admission of hearsay may amount to a denial of natural justice, citing B.(J.) v. Catholic Children's Aid Society of Metropolitan Toronto (1987), 59 O.R. (2d) 417 (Div. Ct.). 
allowed to review this decision on the merits, then the speed and, above all, the finality of the arbitral process is lost. Indeed, arbitration then becomes merely the first step on a ladder which may lead, by way of successive appeals, to the highest court at the place in which the arbitration is held. This preference for finality over legality is reflected in the Model Law and in modern arbitration legislation."

Perhaps the most restricted are the ICC Rules. Article 23 of the ICC Rules provides:

(a) The arbitral award shall be final.

(b) By submitting the dispute to arbitration by the International Chamber of Commerce, the parties shall be deemed to have undertaken to carry out the resulting award without delay and to have waived their right to any form of appeal insofar as such waiver can validly be made.

The UNCITRAL Model Law (which, of course, applies to international commercial arbitrations conducted in Alberta) limits judicial review to these grounds: ${ }^{94}$

(a) A party was under some incapacity;

(b) The arbitration agreement is not valid;

(c) A party was not given proper notice of the appointment of an arbitrator or of the proceedings or was otherwise unable to present its case;

(d) The award deals with matters not falling within the submission to arbitration;

(e) The composition of the arbitral tribunal or procedure was not in accordance with the agreement of the parties;

(f) The subject matter of the dispute is not capable of settlement by arbitration under the laws of the jurisdiction hearing the appeal; and

(g) The award is in conflict with the public policy of the state in which the appeal is heard.

In the United States judicial review of arbitral decisions is similarly restricted without as yet any clear pronouncements from the U.S. Supreme Court as to what the

Redfern \& Hunter, supra note 2 at 435; see Ipswich Borough Council v. Fisons plc [1990], 1 All E.R. 730 (C.A.) at 733 and the prohibition in s. 44(3) of the Alberta Arbitration Act, supra note 4 , which states that "a party may not appeal an award to the court on a question of law which the parties expressly referred to the arbitral tribunal for decision." 
governing test should be. ${ }^{95}$ Morgan observes, "There has certainly been very much less intervention by the legislature and the courts in the conduct of arbitrations, and in that sense, less 'obstruction,' in the United States than in England." 96

Broader opportunities for judicial review exist in England. While most other jurisdictions have tended to defer to the autonomy of international arbitration, the English courts seem to have adopted a different objective. Jaffe, in this regard, stated:

The aim of the 1979 Act was not to create arbitral autonomy, but simply to return the courts to the middle road from which they had strayed in the direction of legal certainty. The unchanged attitude of the English judiciary in interpreting the Act is "to find a correct balance between arbitral autonomy on the one hand and considerations of accuracy in arbitral decision making on questions of law and beneficial development in the growth of English commercial law on the other." In years gone by, arbitration was seen as a challenge to the courts in England. Now, the arbitral and judicial processes have a symbiotic relationship, each dependant upon and benefiting from the other. ${ }^{97}$

The 1979 English Arbitration Act took away the case-stated procedure and appeals for errors of fact on the face of the record. ${ }^{98}$ Thereafter judicial intervention was restricted to these issues:

(a) A question of law that could "substantially affect the rights of one or more of the parties";

(b) Determining a preliminary point of law with the consent either of the arbitrator or the parties;

(c) Ordering the arbitrator in certain circumstances to issue a reasoned award or specify further reasons;

(d) Exercising a general discretion to remit an award to an arbitrator for further consideration; and

(e) Misconduct.

The right to appeal on a question of law is subject to the requirement of obtaining leave of the court which will be granted if the arbitrators "are shown to have gone wrong in law and not to have applied the right legal tests or if, whilst purporting to apply the right legal test, they have reached a conclusion which no reasonable person

The U.S. Supreme Court has, however, clearly indicated that when interpreting arbitration agreements covered by the Federal Arbitration Act, 9 U.S.C.S. (1981), it will give due regard to the federal policy favouring arbitration. For example, ambiguities in the scope of the arbitration clause will be resolved in favour of arbitration. This approach suggests that recourse to the courts will rarely be successful. The AAA Rules state that awards are "final and binding," art. 28(1). See also Mastrobuono, supra note 89. Morgan, supra note 32 at 16. 
could, on the facts which they have found, have reached." ${ }^{199}$ But even that test cannot be applied without qualifications. In the "symbiotic relationship" between arbitral and judicial processes described by Jaffe, in a "one-off" contract involving a dispute with little in the way of general application, leave to appeal in England will not normally be granted unless the tribunal was "obviously wrong on a point of law." 100 This, in the words of Lord Diplock, reflects "the turn of the tide in favour of finality in arbitral awards (particularly in non-domestic arbitrations ...)."101 Where, however, the point of law involves the interpretation of standard terms "rather less strict criteria," it seems, are appropriate ${ }^{102}$ because of the need for clarity and certainty of English commercial law, which an authoritative ruling of the court binding on all arbitrators can usefully provide. $^{103}$

What would constitute misconduct as a ground for judicial intervention under English law is not altogether clear. ${ }^{104}$ Mustill and Boyd suggest it would include a failure to conduct the arbitration in accordance with the submission, behaviour contrary to public policy and behaviour that is, or appears to be, unfair. ${ }^{105}$ The authors do not suggest that unfairness in this context approaches the concept of fairness employed in this article. English law now allows parties to contract out of any right to appeal to the courts on questions of law by entering into an "exclusion agreement" after the dispute arose. ${ }^{106}$

Continental European countries have extremely limited rights of appeal. Since 1981, appeals in France on points of law have been abolished. ${ }^{107}$ In Switzerland the grounds of appeal or review are strictly limited, and parties may agree to exclude even these limited bases of recourse in their arbitration. ${ }^{108}$ In Belgium, recourse to the local courts is excluded in respect of awards made against non-residents of Belgium. ${ }^{109}$

An arbitral award may be set aside, or not enforced in a foreign jurisdiction, for reasons of public policy. ${ }^{110}$ Violations of American antitrust laws are often cited as an example. Another example may relate to an arbitration award that includes interest." Compound interest may arguably be void in England. Any interest may be

Pioneer Shipping Ltd. v. B.T.P. Tioxide Lid., [1981] 2 All E.R. 1030 (HL) at 1047, Lord Roskill [hereinafter The Nema]; see also Antaios Compania Naviera S.A. v. Salen Redenerna A.B., [1985] A.C. 191 (H.L.) and Mustill \& Boyd, supra note 9 at 602-08.

The Nema, ibid. at 1040, Lord Diplock.

Ibid. at 1037.

Ibid. at 1040.

Ibid. at 1036.

See Mustill \& Boyd, supra note 9 at 550-53.

Ibid. at 229 and 551.

Redfern \& Hunter, supra note 2 at 421.

Ibid. at $420,13 \mathrm{n}$.

Ibid. at 421, citing the Swiss PIL Act, c. 12, arts. 190, 192.

P. Bernardini, "The Arbitration Clause of an International Contract" (1992) 9:2 J. Int'l Arb. 45 at 59, citing the Belgian Law of March 27, 1985.

See Redfern \& Hunter, supra note 2 at 443-46.

M. Hunter \& V. Triebel, "Awarding Interest in International Arbitration" (1989) 6 March Arb. 7 at 8-11, 16. 
against public policy in Saudi Arabia. In other countries, interest awarded at a high rate may be considered extortionate. In yet others, the local law may impose strict limitations on the period of time over which interest may be awarded. German law, for example, sets out almost precisely when a party is liable to pay interest, the period over which interest may be awarded, and the rate which must be applied. ${ }^{112}$

Unlike the other areas discussed above, parties may be limited in their ability to create appeal rights when none exist under the jurisdiction in which an appeal is sought. ${ }^{113}$ Because appeal rights are so fundamental to judicial concepts of fairness, parties in drafting arbitration clauses and selecting jurisdictions and rules applicable to international arbitrations should address when and under what circumstances the ability to correct an obviously defective or erroneous arbitration award should be protected. The answer to that question should influence whether an arbitration clause is appropriate at all (as opposed to recourse to an appropriate court) and if so in what jurisdiction.

\section{ENFORCEMENT}

Many of the traditional enforcement problems that plagued international arbitrations have been addressed if not completely answered by conventions and the adoption in certain jurisdictions of legislation recognizing foreign arbitral awards. Countries who have adopted the New York Convention on the Recognition and Enforcement of Foreign Arbitral Awards of $1958^{114}$ have greatly facilitated the enforcement process, although enforcement may be resisted on the same grounds that permit judicial review under art. 36 of the UNCITRAL Model Law referred to above. Not all jurisdictions, however, are signatories to the New York Convention, and grounds for resisting recognition and enforcement of foreign arbitration awards even for signatories to the Convention vary from country to country. ${ }^{115}$ Advice of local counsel in those jurisdictions where enforcement is contemplated is accordingly highly recommended. ${ }^{116}$

\section{CONCLUSION}

I return to the tension or "never-ending battle" between the interests of justice or fairness on the one hand and finality and efficiency on the other. This tension is

lbid. at 16-17.

113 C.P.R. v. Fleming (1893), 22 S.C.R. 33 at 36; Bell Canada v. Office and Professional Employees' Int'l Union, [1974] S.C.R. 335; Halsbury's, supra note 43, vol. 10 at para. 718. Bernardini, supra note 109 at 59, implicitly suggests that any agreement purporting to allow appeals to the local courts will be invalid if the local law excludes any means of recourse to the courts. Recognition and enforcement may also be refused pursuant to art. V(2) of the New York Convention, infra note 114. Casey, supra note 38 at para. 2.1, however, seems to suggest that parties may expressly provide for an appeal, in an arbitration agreement.

Adopted in Alberta as Schedule 1 to the $A I C A A$, supra note 4. For a discussion of the New York Convention see Redfern \& Hunter, supra note 2 at 457-65. countries were signatories to the Convention. 
mirrored in the debate between proselytizers of litigation and those of arbitration. From the writer's perspective this tension is healthy. There is no simple, unequivocal answer as to whether litigation or arbitration will be preferable when weighed on the scales of justice and fairness on the one hand and efficiency and finality on the other. The one and compelling point is that when parties require an adequate assurance of fairness, a standard submission to an arbitration clause typical of many international agreements will not suffice. Undoubtedly countless arbitrations involving, for example, documentary evidence, narrow technical issues, or relatively straightforward fact findings, may be effectively and fairly resolved as a result of standard arbitration clauses. But not all cases will be so straightforward. When disputes become difficult and complex, when credibility factors and disagreements over important evidentiary or opinion matters expand, when most of the relevant facts are in the possession and control of only one party, when the issues become complicated, when multiple parties and jurisdictions are involved, when the principles are important or the amount involved significant, concerns about fundamental fairness in international arbitrations deserve careful consideration. In those cases, utilizing a competent court may become more attractive than arbitration. Alternatively, the creative drafter who can tailor-make a set of detailed rules and procedures in the arbitration agreement may provide parties with greater assurance that the outcome of their dispute will approach the higher standards of faimess inherent in our common law judicial system. 


\begin{tabular}{|c|c|c|c|c|c|c|c|c|}
\hline \multirow[t]{2}{*}{ QUESTION } & \multicolumn{8}{|c|}{ ANSWERS } \\
\hline & $\begin{array}{l}\text { Alberts International } \\
\text { Comowerciel } \\
\text { Arbirretion Aat }\end{array}$ & $\begin{array}{l}\text { Intermationsel Chumber } \\
\text { of Commorice Rutes } \\
\text { (ICC) }\end{array}$ & $\begin{array}{l}\text { American Arbitration } \\
\text { Ausectation } \\
\text { International } \\
\text { Arbisration Rulas } \\
\text { (MAA) }\end{array}$ & $\begin{array}{l}\text { UNCITRAL } \\
\text { Artitrution Rusten, } \\
\text { 1976 }\end{array}$ & $\begin{array}{l}\text { London Court of } \\
\text { International } \\
\text { Arblitration Rulea } \\
\text { (LCIA) }\end{array}$ & $\begin{array}{l}\text { Intermational Bar } \\
\text { Aesoctation } \\
\text { Supplementary Rustes } \\
\text { (IBA) }\end{array}$ & $\begin{array}{l}\text { CPR lnstitule for } \\
\text { Dlspete Resolusion } \\
\text { Model ADR } \\
\text { Procedure }\end{array}$ & 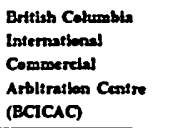 \\
\hline $\begin{array}{l}\text { 1. Do the } \\
\text { Rules provide } \\
\text { for pre- } \\
\text { arbitration } \\
\text { procedures } \\
\text { (such as } \\
\text { mediation) to } \\
\text { resolve the } \\
\text { dispute? }\end{array}$ & $\begin{array}{l}\text { Yes: s. } 5 \text { allows } \\
\text { mediation, } \\
\text { conciliation or } \\
\text { other procedures to } \\
\text { be employed at } \\
\text { any time with the } \\
\text { agreement of the } \\
\text { parties. }\end{array}$ & $\begin{array}{l}\text { Yes. There are } \\
\text { rules for optional } \\
\text { conciliation, if both } \\
\text { parties agree: } \\
\text { art. I-11. }\end{array}$ & $\begin{array}{l}\text { No, although the } \\
\text { introduction } \\
\text { encourages the } \\
\text { partics to consider } \\
\text { mediation or } \\
\text { conciliation and to } \\
\text { discuss such } \\
\text { measures with the } \\
\text { institution. }\end{array}$ & No. & No. & $\begin{array}{l}\text { No, although } \\
\text { art. } 7 \text { (h) may } \\
\text { allow. }\end{array}$ & $\begin{array}{l}\text { Yes, at any time: } \\
\text { r. } 18.1 \text { and } 18.2 \text {. }\end{array}$ & $\begin{array}{l}\text { Yes. Part } 6 \\
\text { includes } \\
\text { conciliation rules } \\
\text { which apply if the } \\
\text { partics agree that } \\
\text { disputes should be } \\
\text { resolved by } \\
\text { amicable } \\
\text { settlement. }\end{array}$ \\
\hline $\begin{array}{l}\text { 2. Is an } \\
\text { arbitrator } \\
\text { required to be } \\
\text { independent and } \\
\text { impartial? }\end{array}$ & $\begin{array}{l}\text { Yes: s. } 11(1) \text {. } \\
\text { Artitrators must } \\
\text { disclose } \\
\text { circumstances } \\
\text { likely to give rise } \\
\text { to justifiable } \\
\text { doubts as to } \\
\text { impartiality or } \\
\text { independence: } \\
\text { Schedule II, } \\
\text { art. 12.1. }\end{array}$ & $\begin{array}{l}\text { Yes: ant. 2.7. An } \\
\text { arbitrator must } \\
\text { remain independent } \\
\text { (no express mention } \\
\text { of impartial). } \\
\text { Arbitrators must } \\
\text { disclose any factors } \\
\text { which may call into } \\
\text { question their } \\
\text { independence: } \\
\text { art. } 2.7 \text {. }\end{array}$ & $\begin{array}{l}\text { Yes, unless the } \\
\text { parties agree } \\
\text { otherwise: an. } 7 \text {. } \\
\text { Arbitrators must } \\
\text { disclose any } \\
\text { circumstances } \\
\text { likely to give rise } \\
\text { to justifiable doubts } \\
\text { as } 10 \text { impartiality or } \\
\text { independence: } \\
\text { ar. } 7 .\end{array}$ & $\begin{array}{l}\text { Yes: art. } 6.4 . \\
\text { Arbitrators must } \\
\text { disclose any } \\
\text { cireumstances } \\
\text { likely to give rise } \\
\text { to justifiable } \\
\text { doubts as to } \\
\text { impartiality or } \\
\text { independence: } \\
\text { art. 9, art. } 10 .\end{array}$ & $\begin{array}{l}\text { Yes: art. } 3.1 \text {. } \\
\text { Arbitrators must } \\
\text { sign a declaration } \\
\text { to that effect and } \\
\text { must forthwith } \\
\text { disclose any } \\
\text { circumstances } \\
\text { likely to give rise } \\
\text { to any justifiable } \\
\text { doubts as to } \\
\text { impartiality and } \\
\text { independence. }\end{array}$ & $\begin{array}{l}\text { No express } \\
\text { provision. }\end{array}$ & $\begin{array}{l}\text { Yes: r. } 7.1 \text {. } \\
\text { Arbitrators must } \\
\text { disclose any } \\
\text { circumstances that } \\
\text { might cause doubt } \\
\text { regarding } \\
\text { independence or } \\
\text { impartiality. } \\
\text { including past } \\
\text { relations: r. } 7.3 \text {. }\end{array}$ & $\begin{array}{l}\text { Yes: ss. } \\
11(1)-11(3) \text {. } \\
\text { Arbitrators must } \\
\text { disclose any } \\
\text { circumstrnces that } \\
\text { might cause doubt } \\
\text { regarding } \\
\text { independence or } \\
\text { impartiality: } \\
\text { ss. II(1). } \\
11(2) \text {. }\end{array}$ \\
\hline $\begin{array}{l}\text { 3. Is the } \\
\text { arbitration } \\
\text { governed by the } \\
\text { nules in force at } \\
\text { the time the } \\
\text { arbitration } \\
\text { agreement was } \\
\text { entered or the } \\
\text { rules in force } \\
\text { when the } \\
\text { arbitration is } \\
\text { initiated? }\end{array}$ & $\begin{array}{l}\text { No express } \\
\text { provision, but see } \\
\text { the definition of } \\
\text { "Intemational } \\
\text { Law" in s. } I(1)(b) \text {. }\end{array}$ & $\begin{array}{l}\text { No express } \\
\text { provision. }\end{array}$ & $\begin{array}{l}\text { The rules in force } \\
\text { at the time the } \\
\text { abitration is } \\
\text { initiated: an. 1.1. }\end{array}$ & $\begin{array}{l}\text { No express } \\
\text { provision in the } \\
\text { Rules themselves. } \\
\text { although the } \\
\text { suggested Model } \\
\text { clause states that } \\
\text { the Rules are those } \\
\text { in force at the time } \\
\text { of the agreement. }\end{array}$ & $\begin{array}{l}\text { No express } \\
\text { provision, although } \\
\text { the preamble } \\
\text { suggests the } \\
\text { applicable nules } \\
\text { are those in force } \\
\text { at the time of the } \\
\text { aritration. }\end{array}$ & $\begin{array}{l}\text { No express } \\
\text { provision. }\end{array}$ & $\begin{array}{l}\text { The Rules in force } \\
\text { at the time the } \\
\text { arbitration is } \\
\text { commenced, unless } \\
\text { the parties agree } \\
\text { otherwise: r. 1.1. }\end{array}$ & $\begin{array}{l}\text { No express } \\
\text { provision. }\end{array}$ \\
\hline
\end{tabular}




\begin{tabular}{|c|c|c|c|c|c|c|c|c|}
\hline \multirow[t]{2}{*}{ QUESTION } & \multicolumn{8}{|c|}{ ANSWERS } \\
\hline & $\begin{array}{l}\text { Aberta Internationsel } \\
\text { Consumecial } \\
\text { Arbitration Ad }\end{array}$ & $\begin{array}{l}\text { Intermationel Chamber } \\
\text { of Commoner Rules } \\
\text { (ICS) }\end{array}$ & 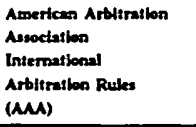 & $\begin{array}{l}\text { UNCTTRAL } \\
\text { Artitration Rulea, } \\
\text { 1976 }\end{array}$ & $\begin{array}{l}\text { London Court of } \\
\text { Intermatlonel } \\
\text { Artitration Rubs } \\
\text { (LCLA) }\end{array}$ & $\begin{array}{l}\text { International Bar } \\
\text { Assoctation } \\
\text { Supplementary Rusles } \\
\text { (IBA) }\end{array}$ & $\begin{array}{l}\text { CPR lisasitute for } \\
\text { Dispute Resolution } \\
\text { Moded ADR } \\
\text { Procedure }\end{array}$ & $\begin{array}{l}\text { Brtizh Colmonbis } \\
\text { lniemetional } \\
\text { Commeredal } \\
\text { Arbitration Centre } \\
\text { (BCICAC) }\end{array}$ \\
\hline $\begin{array}{l}\text { 4. Absent an } \\
\text { express } \\
\text { agreement by } \\
\text { the parties, how } \\
\text { many arbitrators } \\
\text { will be } \\
\text { selected? }\end{array}$ & $\begin{array}{l}\text { Three: Schedale II, } \\
\text { art. 10.2. }\end{array}$ & $\begin{array}{l}\text { One, unless the } \\
\text { institution (the } \\
\text { International Court } \\
\text { of Arbitration) feels } \\
\text { that the dispute } \\
\text { warants three: } \\
\text { art } 2.5 \text {. }\end{array}$ & $\begin{array}{l}\text { One, unless the } \\
\text { administrator } \\
\text { determines that } \\
\text { three are } \\
\text { appropriate because } \\
\text { of the case's size, } \\
\text { complexity or other } \\
\text { circumstances: } \\
\text { ar. } 5 \text {. }\end{array}$ & Three: art. 5. & $\begin{array}{l}\text { Onc, unless the } \\
\text { LCIA determines } \\
\text { that a three- } \\
\text { member tribunal is } \\
\text { appropriate in the } \\
\text { circumstances: } \\
\text { art. } 3.2 \text {. }\end{array}$ & $\begin{array}{l}\text { No express } \\
\text { provision. }\end{array}$ & Three: r. S.I. & Three: s. 5. \\
\hline $\begin{array}{l}\text { 5. Must } \\
\text { abitrators be } \\
\text { chosen from a } \\
\text { country other } \\
\text { than those of } \\
\text { which the } \\
\text { parties are } \\
\text { nationals? }\end{array}$ & $\begin{array}{l}\text { No, unless the } \\
\text { parties agree } \\
\text { otherwise: } \\
\text { Schedule II. } \\
\text { art. I1.1. } \\
\text { However, } \\
\text { nationality is a } \\
\text { factor taken into } \\
\text { account if the } \\
\text { court is making the } \\
\text { appointment: } \\
\text { Schedule II. } \\
\text { art. 11.5. }\end{array}$ & $\begin{array}{l}\text { Yes, with respect to } \\
\text { a sole abitrator or } \\
\text { chaiman. } \\
\text { However, discretion } \\
\text { exists :o appoint } \\
\text { nationals if neither } \\
\text { of the parties object: } \\
\text { art. } 2.6 \text {. }\end{array}$ & $\begin{array}{l}\text { Not necessarily, } \\
\text { although arbitrators } \\
\text { must be "suitable". } \\
\text { Any party may } \\
\text { request an arbitrator } \\
\text { be appointed from a } \\
\text { country other than } \\
\text { that of any of the } \\
\text { partics: art. } 6.4 \text {. }\end{array}$ & $\begin{array}{l}\text { Not necessarily. } \\
\text { However, the } \\
\text { advisebility of } \\
\text { appointing an } \\
\text { abitrator of a } \\
\text { nationality other } \\
\text { than that of the } \\
\text { parties is a factor } \\
\text { taken into account } \\
\text { when assessing the } \\
\text { asbitrator's } \\
\text { independence and } \\
\text { impartiality: } \\
\text { an. } 6.4 \text {. }\end{array}$ & $\begin{array}{l}\text { Yes, with regard } \\
\text { to sole arbitrators } \\
\text { or chairs. (The } \\
\text { nationality of a } \\
\text { party expressly } \\
\text { includes } \\
\text { controlling } \\
\text { shareholders or } \\
\text { interests): art. } 3.3 \text {. } \\
\text { However, the } \\
\text { parties may agree } \\
\text { otherwise. }\end{array}$ & $\begin{array}{l}\text { No express } \\
\text { provision. }\end{array}$ & $\begin{array}{l}\text { Not necessasily. } \\
\text { Eech potential } \\
\text { arbitrator must, } \\
\text { however, disclose } \\
\text { any circumstances } \\
\text { which might cast } \\
\text { doubt on their } \\
\text { inpartiality. } \\
\text { including past } \\
\text { relations: } r \text {. } 7.3 \text {. } \\
\text { The nationality of } \\
\text { the arbitrators can } \\
\text { be stipulated: } \\
\text { Introductory } \\
\text { commentaries, B. }\end{array}$ & $\begin{array}{l}\text { Not necessarily, } \\
\text { although if the } \\
\text { BCICAC is } \\
\text { appointing an } \\
\text { atitrator, it shall } \\
\text { have due regard to } \\
\text { the advisability of } \\
\text { appointing an } \\
\text { arbitrator of a } \\
\text { netionality other } \\
\text { than thosc of the } \\
\text { parties: } s .8(3)(c) \text {. }\end{array}$ \\
\hline
\end{tabular}




\begin{tabular}{|c|c|c|c|c|c|c|c|c|}
\hline \multirow[t]{2}{*}{ QUESTION } & \multicolumn{8}{|c|}{ ANSWERS } \\
\hline & $\begin{array}{l}\text { Alberts Intermational } \\
\text { Comomercial } \\
\text { Arbitretion Ad }\end{array}$ & $\begin{array}{l}\text { Internatienal Chamber } \\
\text { of Commerce Rules } \\
\text { (ICC) }\end{array}$ & 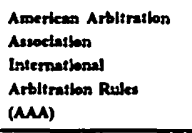 & $\begin{array}{l}\text { UNCITRul. } \\
\text { Afbitration Rukes, } \\
1976\end{array}$ & $\begin{array}{l}\text { London Court of } \\
\text { Intematlossl } \\
\text { Arblirallos Rules } \\
\text { (LCIA) }\end{array}$ & $\begin{array}{l}\text { Intemational Bar } \\
\text { Alsociation } \\
\text { Supplementany Rules } \\
\text { (IBA) }\end{array}$ & $\begin{array}{l}\text { CPR Inatitute for } \\
\text { Dlapuse Resolution } \\
\text { Model ADR } \\
\text { Procedture }\end{array}$ & $\begin{array}{l}\text { Britith Cotumbla } \\
\text { Intemetiogel } \\
\text { Commencial } \\
\text { Artitration Centre } \\
\text { (BCICAC) }\end{array}$ \\
\hline $\begin{array}{l}\text { 6. How is an } \\
\text { arbitrator } \\
\text { selected if the } \\
\text { parties are } \\
\text { unable to } \\
\text { agree? }\end{array}$ & $\begin{array}{l}\text { By the Court of } \\
\text { Queen's Bench, at } \\
\text { the request of a } \\
\text { party: Schedule II, } \\
\text { an. 11.3. }\end{array}$ & $\begin{array}{l}\text { If the parties have } \\
\text { not agreed within } \\
30 \text { days, the } \\
\text { institution will } \\
\text { appoint an arbitrator } \\
\text { after consulting with } \\
\text { the national } \\
\text { committees it } \\
\text { considers } \\
\text { appropriate: } \\
\text { arts. } 2.3,2.6 \text {. }\end{array}$ & $\begin{array}{l}\text { If the parties have } \\
\text { not agreed on an } \\
\text { arbitrator within } \\
60 \text { days after the } \\
\text { commencement of } \\
\text { the arbitration, the } \\
\text { institution will } \\
\text { appoint the } \\
\text { astitrator(s) after } \\
\text { consuluation with } \\
\text { the parties: ant. } 6.3 \text {. }\end{array}$ & $\begin{array}{l}\text { If the parties have } \\
\text { not agreed within } \\
30 \text { days after } \\
\text { receiving a notice } \\
\text { of proposed } \\
\text { arbitrator, the } \\
\text { appointing } \\
\text { authority will } \\
\text { appoint an } \\
\text { arbitrator. } \\
\text { Generally, list } \\
\text { procedures are } \\
\text { used for a sole } \\
\text { arbitrator or chair. } \\
\text { If the parties have } \\
\text { not designated an } \\
\text { appointing } \\
\text { authority, any } \\
\text { party may request } \\
\text { that the Permanent } \\
\text { Court of } \\
\text { Arbitration } \\
\text { designate an } \\
\text { arbitrator: ants. } 6.1 \text {. } \\
6.2,6.3,7.1,7.2 \text {, } \\
7.3 \text {. }\end{array}$ & $\begin{array}{l}\text { The LCIA will } \\
\text { appoint the } \\
\text { tribunal if no } \\
\text { response is } \\
\text { received by the } \\
\text { Respondent within } \\
30 \text { days of } \\
\text { receiving the } \\
\text { Request for } \\
\text { Arbitration: } \\
\text { arts. } 3.2,3.4 \text {. } \\
\text { (Additionally, the } \\
\text { LCLA may refuse } \\
\text { to appoint party } \\
\text { nominees if it } \\
\text { determines they } \\
\text { ase not suitable. } \\
\text { impartial or } \\
\text { independent: } \\
\text { art. } 3.3 \text { ). }\end{array}$ & $\begin{array}{l}\text { No express } \\
\text { provision. }\end{array}$ & $\begin{array}{l}\text { If the parties fail } \\
\text { to appoint } \\
\text { arbitrators within } \\
20 \text { days after the } \\
\text { notice of defence, } \\
\text { or if the arbitrators } \\
\text { are unable to } \\
\text { select a chair } \\
\text { within } 20 \text { days of } \\
\text { their initial } \\
\text { discussion, either } \\
\text { party may request } \\
\text { that the neutral } \\
\text { organization select } \\
\text { an arbitrator. } \\
\text { There are } \\
\text { provisions for a } \\
\text { list procedure: } \\
\text { 8. } 6.1-6.4 \text {. }\end{array}$ & $\begin{array}{l}\text { If the parties fail } \\
\text { to agree on an } \\
\text { arbirator within } \\
30 \text { days of an } \\
\text { abitrator being } \\
\text { proposed, or if two } \\
\text { arbitrators fail to } \\
\text { select a chair } \\
\text { within } 30 \text { days of } \\
\text { the last arbitrator's } \\
\text { appointment, a } \\
\text { party may request } \\
\text { that the institution } \\
\text { appoint an } \\
\text { antitrator: ss. } 6,7 \text {. } \\
\text { Normally, a list } \\
\text { procedure is used: } \\
\text { an. } 8 \text {. }\end{array}$ \\
\hline $\begin{array}{l}\text { 7. Absent an } \\
\text { agreement by } \\
\text { the parties, how } \\
\text { is the place of } \\
\text { arbitration } \\
\text { determined? }\end{array}$ & $\begin{array}{l}\text { By the tribunal, } \\
\text { having regard to } \\
\text { the circumstances, } \\
\text { including the } \\
\text { convenience of the } \\
\text { parties: } \\
\text { Schedule II. } \\
\text { art. } 20.2\end{array}$ & $\begin{array}{l}\text { By the institution: } \\
\text { ar. } 12 .\end{array}$ & $\begin{array}{l}\text { By the } \\
\text { administrator, } \\
\text { although this } \\
\text { decision is subject } \\
\text { to a deermination } \\
\text { by the tribunal, } \\
\text { having regard for } \\
\text { the parties' } \\
\text { contentions and the } \\
\text { circumstanees: } \\
\text { art. 13.1. }\end{array}$ & $\begin{array}{l}\text { By the arbitral } \\
\text { tribunal, having } \\
\text { regard to the } \\
\text { circumstances: } \\
\text { ar. } 16.1 \text {. }\end{array}$ & $\begin{array}{l}\text { The place of } \\
\text { asbitration will be } \\
\text { London, unless the } \\
\text { tribunal determines } \\
\text { in view of the } \\
\text { circumstances that } \\
\text { another place is } \\
\text { more appropriate: } \\
\text { ar. } 7.1 \text {. }\end{array}$ & $\begin{array}{l}\text { No express } \\
\text { provision. }\end{array}$ & $\begin{array}{l}\text { By the tribunal: } \\
\text { r. } 9.6 \text {. }\end{array}$ & $\begin{array}{l}\text { The place of } \\
\text { arbitration shall be } \\
\text { Vancouver. } \\
\text { s. } 20(1) \text {. }\end{array}$ \\
\hline
\end{tabular}




\begin{tabular}{|c|c|c|c|c|c|c|c|c|}
\hline \multirow[t]{2}{*}{ QUESTION } & \multicolumn{8}{|c|}{ ANSWERS } \\
\hline & $\begin{array}{l}\text { Aberts Imetemetional } \\
\text { Convinecial } \\
\text { Arbitration Ad }\end{array}$ & $\begin{array}{l}\text { International Chamber } \\
\text { of Comiseree Rules } \\
\text { (ICC) }\end{array}$ & 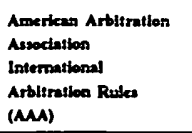 & $\begin{array}{l}\text { UNCTIRAL } \\
\text { Arbitretion Ruskes, } \\
\text { 1976 }\end{array}$ & $\begin{array}{l}\text { London Court of } \\
\text { Intemattonal } \\
\text { Arbitration Rules } \\
\text { (LC1A) }\end{array}$ & $\begin{array}{l}\text { Intemsilonal Bar } \\
\text { Asuocintlon } \\
\text { Supplementary Rules } \\
\text { (IBA) }\end{array}$ & $\begin{array}{l}\text { CPR Lnstitute for } \\
\text { Dispete Resolution } \\
\text { Model ADR } \\
\text { Procedure }\end{array}$ & $\begin{array}{l}\text { BAtlah Columbla } \\
\text { Intersational } \\
\text { Commerdil } \\
\text { Artitsation Contre } \\
\text { (BCICAC) }\end{array}$ \\
\hline $\begin{array}{l}\text { 8. Are } \\
\text { jurisdictional } \\
\text { challenges } \\
\text { determined at } \\
\text { the outset of at } \\
\text { the end of the } \\
\text { merits? }\end{array}$ & $\begin{array}{l}\text { The arbitrators } \\
\text { may decide: } \\
\text { Schedule II, } \\
\text { art. } 16.2 \text {. }\end{array}$ & $\begin{array}{l}\text { The arbitrator likely } \\
\text { has discretion: } \\
\text { ant } 8.3 \text {. }\end{array}$ & $\begin{array}{l}\text { No express } \\
\text { provision. }\end{array}$ & $\begin{array}{l}\text { Generally, the } \\
\text { tribunal should } \\
\text { rule on such issues } \\
\text { as a preliminary } \\
\text { question, but has } \\
\text { discretion to } \\
\text { proceed and issue } \\
\text { jurisdictiona! } \\
\text { orders after the } \\
\text { merits are heard: } \\
\text { art. } 21.4 \text {. }\end{array}$ & $\begin{array}{l}\text { No express } \\
\text { provision. The } \\
\text { arbitrator likely } \\
\text { has discretion: } \\
\text { art. } 5.2 \text {. }\end{array}$ & $\begin{array}{l}\text { No express } \\
\text { provision. }\end{array}$ & $\begin{array}{l}\text { The arbitrator may } \\
\text { decide: } \\
\text { commentary to } \\
\text { r. } 8 \text {. }\end{array}$ & $\begin{array}{l}\text { The arbitrator may } \\
\text { decide: s. } 15(5) \text {. }\end{array}$ \\
\hline $\begin{array}{l}\text { 9. May the } \\
\text { arbitration } \\
\text { proceed if a } \\
\text { party fails to } \\
\text { take par? }\end{array}$ & $\begin{array}{l}\text { Generally, yes: } \\
\text { Schedule II, ant. } \\
25 \text {. }\end{array}$ & $\begin{array}{l}\text { Yes: an. 8.2. } \\
\text { art. 15.2. }\end{array}$ & $\begin{array}{l}\text { Yes, if the } \\
\text { defaulting party has } \\
\text { not shown } \\
\text { suficiest cause: } \\
\text { an. } 24 \text {. }\end{array}$ & $\begin{array}{l}\text { Yes, if the } \\
\text { defaulting party } \\
\text { has not shown } \\
\text { sufficient cause: } \\
\text { art. } 28 \text {. }\end{array}$ & $\begin{array}{l}\text { Yes: art. } 3.2 \text {, } \\
\text { art. } 6.7 \text {. The } \\
\text { defaulting party } \\
\text { must be given } \\
\text { notice, however: } \\
\text { art. } 14.3 \text {. }\end{array}$ & $\begin{array}{l}\text { No express } \\
\text { provision. }\end{array}$ & Yes: t. 15. & $\begin{array}{l}\text { Yes, if the } \\
\text { defaulting party } \\
\text { has not shown } \\
\text { sufficient cause: } \\
\text { ss. } 28(3), 28(4)\end{array}$ \\
\hline $\begin{array}{l}\text { 10. Must } \\
\text { parties be } \\
\text { treated with } \\
\text { equality and be } \\
\text { given a full } \\
\text { opportunity of } \\
\text { presenting their } \\
\text { case? }\end{array}$ & $\begin{array}{l}\text { Yes: Schedule II, } \\
\text { art. } 18 .\end{array}$ & $\begin{array}{l}\text { No express } \\
\text { provision. } \\
\text { Although, all parties } \\
\text { are entitled to be } \\
\text { present (art. 15.4), } \\
\text { no express provision } \\
\text { requires them to be } \\
\text { heard (although it } \\
\text { may be implicit in } \\
\text { arts. } 14.1 \text { and/or } \\
2.6 \text { ). }\end{array}$ & Yes: art. 16.1. & Yes: art. is. & $\begin{array}{l}\text { No express } \\
\text { provision, but may } \\
\text { be implied by } \\
\text { ars. } 10.1 \text { and } 20.2 \text {. } \\
\text { Sec also art. } 13.1 \text {. }\end{array}$ & $\begin{array}{l}\text { No express } \\
\text { provision. }\end{array}$ & $\begin{array}{l}\text { No express } \\
\text { provision. }\end{array}$ & Yes: s. 19(1). \\
\hline
\end{tabular}




\begin{tabular}{|c|c|c|c|c|c|c|c|c|}
\hline \multirow[t]{2}{*}{ QUESTION } & \multicolumn{8}{|c|}{ ANSWERS } \\
\hline & $\begin{array}{l}\text { Alberts International } \\
\text { Commercial } \\
\text { Arbitration Adet }\end{array}$ & $\begin{array}{l}\text { Intemational Chumber } \\
\text { of Comsacree Rules } \\
\text { (ICC) }\end{array}$ & $\begin{array}{l}\text { American Arblitration } \\
\text { Assoctation } \\
\text { Intermational } \\
\text { Arblitration Rulke } \\
\text { (AMA) }\end{array}$ & $\begin{array}{l}\text { UNCITRAL } \\
\text { Arbitration Rules, } \\
1976\end{array}$ & $\begin{array}{l}\text { London Coust of } \\
\text { Internatlona! } \\
\text { Arbitratlon Rules } \\
\text { (LCIA) }\end{array}$ & $\begin{array}{l}\text { Intermationsl Bar } \\
\text { Assoctaslon } \\
\text { Supplementary Rulet } \\
\text { (IBA) }\end{array}$ & $\begin{array}{l}\text { CPR Institute for } \\
\text { Dispute Resolution } \\
\text { Modet ADR } \\
\text { Procedure }\end{array}$ & $\begin{array}{l}\text { Bertish Columbita } \\
\text { International } \\
\text { Commorelal } \\
\text { Astitration Centre } \\
\text { (BCICAC) }\end{array}$ \\
\hline $\begin{array}{l}\text { 11. May the } \\
\text { abitrator order } \\
\text { production of } \\
\text { documents prior } \\
\text { to the hearing? }\end{array}$ & $\begin{array}{l}\text { Unclear, but if a } \\
\text { party does not } \\
\text { produce } \\
\text { documentary } \\
\text { evidence, the } \\
\text { atitrator can } \\
\text { decide on evidence } \\
\text { before it: } \\
\text { Schedule il. } \\
\text { ar. } 25(\text { c). }\end{array}$ & $\begin{array}{l}\text { Unclear. There is } \\
\text { no express provision } \\
\text { regarding production } \\
\text { of evidence, but the } \\
\text { arbitrator has wide } \\
\text { discretion to fashion } \\
\text { procedural rules, } \\
\text { absent an agreement } \\
\text { by the parties: } \\
\text { art. } 11 \text {. }\end{array}$ & $\begin{array}{l}\text { Yes: ar. } 20.2 \text {. } \\
\text { Production may } \\
\text { also be ordered } \\
\text { during the hearing: } \\
\text { ar. } 20.3 \text {. }\end{array}$ & $\begin{array}{l}\text { Yes, if the } \\
\text { arbitrator considers } \\
\text { it appropriate: } \\
\text { arts. 24.3, 24.2. }\end{array}$ & $\begin{array}{l}\text { Yes. The tribunal } \\
\text { may order any } \\
\text { party to supply } \\
\text { copies of any } \\
\text { documents or } \\
\text { classes of } \\
\text { documents in their } \\
\text { possession or } \\
\text { power which the } \\
\text { tribunal determines } \\
\text { to be relevant: } \\
\text { ar. } 13.1(\text { i). }\end{array}$ & $\begin{array}{l}\text { Yes: ant. 4.4. If a } \\
\text { request by another } \\
\text { party to produce a } \\
\text { reasonably } \\
\text { identified } \\
\text { document has been } \\
\text { refused, the } \\
\text { arbitrator may } \\
\text { order it to be } \\
\text { produced (not } \\
\text { applicable to } \\
\text { internal } \\
\text { documents). } \\
\text { art. } 4.5 \text { also allows } \\
\text { the arbitrator to } \\
\text { order a party to } \\
\text { produce any } \\
\text { relevant document } \\
\text { within its } \\
\text { possession, custody } \\
\text { of control. }\end{array}$ & $\begin{array}{l}\text { Probably. The } \\
\text { tribunal may } \\
\text { require the parties } \\
\text { to produce } \\
\text { evidence in } \\
\text { addition to that } \\
\text { initially offered: } \\
\text { r. } 12.3 \text {. }\end{array}$ & Yes: s. 25(3). \\
\hline $\begin{array}{l}\text { 12. May the } \\
\text { parties conduct } \\
\text { oral } \\
\text { discoveries? }\end{array}$ & $\begin{array}{l}\text { No express } \\
\text { provision. }\end{array}$ & $\begin{array}{l}\text { No express } \\
\text { provision. }\end{array}$ & $\begin{array}{l}\text { No express } \\
\text { provision. }\end{array}$ & $\begin{array}{l}\text { No express } \\
\text { provision, although } \\
\text { the ability to } \\
\text { require parties to } \\
\text { produce "other } \\
\text { evidence" in } \\
\text { art. } 24.3 \text { may } \\
\text { allow. }\end{array}$ & Yes: art. 11.5. & $\begin{array}{l}\text { Yes? art. } 5.8 \\
\text { allows parties to } \\
\text { "interview } \\
\text { witnesses or } \\
\text { potential } \\
\text { witnesses". } \\
\text { arts. } 1.2,5.14,6.2 \text {. } \\
\text { An. } 7 \text { (h) may also } \\
\text { allow. }\end{array}$ & $\begin{array}{l}\text { No express } \\
\text { provision, although } \\
\text { r. } 11 \text { may allow. }\end{array}$ & $\begin{array}{l}\text { Yes: s. } 27(4) \text {. } \\
\text { ss. } 25(3) .26(2) \\
\text { also likely allow. }\end{array}$ \\
\hline
\end{tabular}




\begin{tabular}{|c|c|c|c|c|c|c|c|c|}
\hline \multirow[t]{2}{*}{ QUESTION } & \multicolumn{8}{|c|}{ ANSWERS } \\
\hline & $\begin{array}{l}\text { Abberts Imsermetional } \\
\text { Commorcial } \\
\text { Asbirration Act }\end{array}$ & $\begin{array}{l}\text { International Chamber } \\
\text { of Commerer Rubes } \\
\text { (ICC) }\end{array}$ & 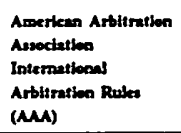 & $\begin{array}{l}\text { UNCITRAL } \\
\text { Arbitratbon Ruske, } \\
1976\end{array}$ & $\begin{array}{l}\text { Losdon Court of } \\
\text { International } \\
\text { Arbltintion Rules } \\
\text { (LCLA) }\end{array}$ & $\begin{array}{l}\text { Intermetiossel Bar } \\
\text { Aesootestion } \\
\text { Sepplementary Rules } \\
\text { (IBA) }\end{array}$ & $\begin{array}{l}\text { CPR Inotitute for } \\
\text { Dispete Resolution } \\
\text { Model ADR } \\
\text { Procedrere }\end{array}$ & 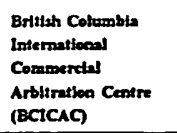 \\
\hline $\begin{array}{l}\text { 13. (a) May } \\
\text { the arbitrator } \\
\text { make interim } \\
\text { orders? }\end{array}$ & $\begin{array}{l}\text { Yes to preserve the } \\
\text { subject matter of } \\
\text { the dispute, and } \\
\text { specifically allows } \\
\text { for the security for } \\
\text { costs of stch } \\
\text { measures, as the } \\
\text { abitrator[s] } \\
\text { "consider[s] } \\
\text { necessary": } \\
\text { Schedule II. } \\
\text { ar. } 17 \text {. }\end{array}$ & $\begin{array}{l}\text { No express } \\
\text { provision, but } \\
\text { art } 11 \text { may allow. }\end{array}$ & $\begin{array}{l}\text { Yes: ar. } 22 \text { allows } \\
\text { such awards to } \\
\text { protect the subject } \\
\text { matrer of the } \\
\text { dispute and } \\
\text { specifically allows } \\
\text { for security of the } \\
\text { costs for such } \\
\text { measures. }\end{array}$ & $\begin{array}{l}\text { Yes, to preserve } \\
\text { the subject matter } \\
\text { of the dispute and } \\
\text { specifically allows } \\
\text { security for costs: } \\
\text { art. } 26.1 \text {. }\end{array}$ & $\begin{array}{l}\text { Yes: arts. } 13.1(\mathrm{~h}) \text {, } \\
15.2 \text { and } 15.4, \text { to } \\
\text { preserve property } \\
\text { and provide } \\
\text { security for costs. } \\
\text { ant. } 5.2 \text { may } \\
\text { provide a more } \\
\text { general powver to } \\
\text { issuc interim } \\
\text { awards. }\end{array}$ & $\begin{array}{l}\text { No express } \\
\text { provision, although } \\
\text { arts. } 1.2,7(\text { h) may } \\
\text { allow. }\end{array}$ & $\begin{array}{l}\text { Yes, as it deems } \\
\text { necessary and at } \\
\text { the request of a } \\
\text { party, to preserve } \\
\text { assets. Security } \\
\text { for the costs of } \\
\text { such measures is } \\
\text { specifically } \\
\text { allowed: r. 13.1. }\end{array}$ & $\begin{array}{l}\text { Interim measures } \\
\text { of protection may } \\
\text { be ordered, } \\
\text { including } \\
\text { providing security } \\
\text { in connection with } \\
\text { such measures: } \\
\text { ss. } 16(1), 16(2) \text {. }\end{array}$ \\
\hline $\begin{array}{l}\text { (b) May } \\
\text { assistance be } \\
\text { sought from the } \\
\text { Courts for } \\
\text { interim } \\
\text { measures? }\end{array}$ & $\begin{array}{l}\text { Yes: Schedule II, } \\
\text { art. } 9 .\end{array}$ & $\begin{array}{l}\text { Yes, if application is } \\
\text { made to the courts } \\
\text { before the file is } \\
\text { transmitted to the } \\
\text { abitration, and in } \\
\text { exceptional } \\
\text { circumstances } \\
\text { thereafter. ant } 8.4 \text {. }\end{array}$ & $\begin{array}{l}\text { Yes, to protect the } \\
\text { subject matrer of } \\
\text { the dispute: } \\
\text { ar. 22.3. }\end{array}$ & Yes: art. 26.3 . & $\begin{array}{l}\text { Yes, for pre-award } \\
\text { conservetory } \\
\text { measures, except } \\
\text { those in arts. 15.1, } \\
\text { 15.2: art. 15.4. }\end{array}$ & $\begin{array}{l}\text { No express } \\
\text { provision. }\end{array}$ & Yes: r. 13.2 & $\begin{array}{l}\text { No express } \\
\text { provision in the } \\
\text { Rules. }\end{array}$ \\
\hline
\end{tabular}




\begin{tabular}{|c|c|c|c|c|c|c|c|c|}
\hline \multirow[t]{2}{*}{ QUESTION } & \multicolumn{8}{|c|}{ ANSWERS } \\
\hline & $\begin{array}{l}\text { Alberta Insernetional } \\
\text { Comsercial } \\
\text { Aodiretion Ada }\end{array}$ & $\begin{array}{l}\text { International Chamber } \\
\text { of Commeres Ruste } \\
\text { (ICC) }\end{array}$ & 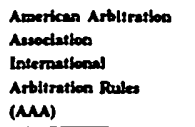 & $\begin{array}{l}\text { UNCrTrul } \\
\text { Artitration Reske, } \\
\text { I976 }\end{array}$ & $\begin{array}{l}\text { London Court of } \\
\text { International } \\
\text { Arbliration Rules } \\
\text { (LCL) }\end{array}$ & 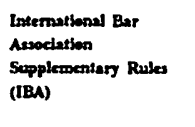 & $\begin{array}{l}\text { CPR Imstitute for } \\
\text { Dispouse Resolution } \\
\text { Model ADR } \\
\text { Procedure }\end{array}$ & 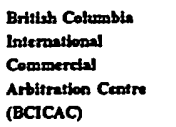 \\
\hline $\begin{array}{l}\text { 14. Must there } \\
\text { be an oral } \\
\text { hearing? }\end{array}$ & $\begin{array}{l}\text { Yes, if requested } \\
\text { by a party and } \\
\text { unless the parties } \\
\text { agree otherwise. } \\
\text { Otherwise, the } \\
\text { abitrator may } \\
\text { choose whether to } \\
\text { conduct the } \\
\text { proceedings on the } \\
\text { basis of documents } \\
\text { or whether to hold } \\
\text { oral hearings: } \\
\text { Schedule II. } \\
\text { art. } 24.1 \text {. }\end{array}$ & $\begin{array}{l}\text { Yes, if requested by } \\
\text { a party. Otherwise, } \\
\text { the artitrator may } \\
\text { decide: arts. 14.1, } \\
\text { 15.1. The parties } \\
\text { may request or } \\
\text { agree that the case } \\
\text { be decided based } \\
\text { upon documents } \\
\text { alone: art. } 14.3 \text {. }\end{array}$ & $\begin{array}{l}\text { Not necessarily. } \\
\text { The tribunal has the } \\
\text { ability to choose } \\
\text { whatever manner it } \\
\text { deems appropriate: } \\
\text { an. } 16 \text {. (However. } \\
\text { an. } 21 \text { refers to } \\
\text { "the" initial oral } \\
\text { hearing and may } \\
\text { implicity require an } \\
\text { oral hearing.) }\end{array}$ & $\begin{array}{l}\text { Yes, if either party } \\
\text { requests it. If } \\
\text { neither does, the } \\
\text { tribunal can } \\
\text { choose: ar. } 15.2 \text {. }\end{array}$ & $\begin{array}{l}\text { Yes, unless the } \\
\text { partices have agreed } \\
\text { otherwise: } \\
\text { ant. } 10.1 \text {. }\end{array}$ & $\begin{array}{l}\text { The arbitrator has } \\
\text { discretion to order } \\
\text { any witness to give } \\
\text { oral evidence: } \\
\text { arts. 5.6, 5.7, 5.14. } \\
\text { Although the } \\
\text { parties may agree } \\
\text { on an oral hearing. } \\
\text { At all times, the } \\
\text { arbitrator may limit } \\
\text { or deny rights of } \\
\text { examination if such } \\
\text { evidence is } \\
\text { unlikely to serve } \\
\text { any further relevant } \\
\text { purpose: art. } 5.10 \text {. } \\
\text { See also art. } 7(\text { b), } \\
\text { (c), (8), (h). }\end{array}$ & $\begin{array}{l}\text { Not necessarily. } \\
\text { The tribunal may } \\
\text { decide whether } \\
\text { evidence will be } \\
\text { presented in oral } \\
\text { or written form: } \\
\text { r. } 12.2 \text {. }\end{array}$ & $\begin{array}{l}\text { Yes, if either party } \\
\text { requests it: } \\
\text { s. } 26(2) \text {. } \\
\text { Otherwise, the } \\
\text { atbitrator shall } \\
\text { decide: s. } 26(1) \text {. }\end{array}$ \\
\hline $\begin{array}{l}\text { 15. Any } \\
\text { explicit tight to } \\
\text { cross-examine } \\
\text { witnesses? }\end{array}$ & $\begin{array}{l}\text { Only in relation to } \\
\text { expers, unless } \\
\text { agreed to by the } \\
\text { paries: an. } 26.2 \text {. }\end{array}$ & $\begin{array}{l}\text { No express } \\
\text { provision. }\end{array}$ & $\begin{array}{l}\text { Only in relation to } \\
\text { experts, at the } \\
\text { request of a party: } \\
\text { ar. } 23.4 \text {. }\end{array}$ & $\begin{array}{l}\text { Only in relation to } \\
\text { experts appointed } \\
\text { by the tribunal: } \\
\text { art. } 27.4 \text {. }\end{array}$ & $\begin{array}{l}\text { Yes. "Any } \\
\text { witness who gives } \\
\text { oral evidence may } \\
\text { be questioned by } \\
\text { each of the parties } \\
\text { or their legal } \\
\text { practioners, under } \\
\text { the control of the } \\
\text { tribunal": art. } 11.3 \text {. }\end{array}$ & $\begin{array}{l}\text { Yes, for any } \\
\text { witness giving oral } \\
\text { evidence: an. } 5.9 \text {, } \\
\text { but the arbitrator } \\
\text { may limit or deny } \\
\text { cross-examination } \\
\text { if such evidence is } \\
\text { unlikely to serve } \\
\text { any further relevant } \\
\text { purpose: ar. } 5.10 \text {. }\end{array}$ & $\begin{array}{l}\text { Yes, in relation to } \\
\text { experts (ar. 12.3) } \\
\text { but not necessarily } \\
\text { with other } \\
\text { witnesses. The } \\
\text { tribunal can } \\
\text { choose the manner } \\
\text { in which witneases } \\
\text { are examined: } r \text {. } \\
12.4 \text {. }\end{array}$ & $\begin{array}{l}\text { Only in relation to } \\
\text { experts, if a party } \\
\text { so requests or the } \\
\text { tribunal considess } \\
\text { it necessary: s. } \\
29(6)(a) \text {. }\end{array}$ \\
\hline
\end{tabular}




\begin{tabular}{|c|c|c|c|c|c|c|c|c|}
\hline \multirow[t]{2}{*}{ QUESTION } & \multicolumn{8}{|c|}{ ANSWERS } \\
\hline & $\begin{array}{l}\text { Aberts International } \\
\text { Cowmercial } \\
\text { Arbioretion Act }\end{array}$ & $\begin{array}{l}\text { Ireermetbonal Chamber } \\
\text { of Commerce Rules } \\
\text { (ICS) }\end{array}$ & 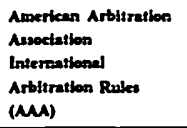 & $\begin{array}{l}\text { UNCITRAL } \\
\text { Arbitirntion Reviles, } \\
1976\end{array}$ & $\begin{array}{l}\text { Londen Coust of } \\
\text { Intemational } \\
\text { Arbitration Rulles } \\
\text { (LCLA) }\end{array}$ & 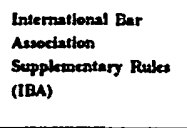 & $\begin{array}{l}\text { CPR Imatiture for } \\
\text { Dispute Resofution } \\
\text { Model ADR } \\
\text { Procedure }\end{array}$ & $\begin{array}{l}\text { British Columbia } \\
\text { International } \\
\text { Compoercial } \\
\text { Arbilintion Contre } \\
\text { (BCTCAC) }\end{array}$ \\
\hline $\begin{array}{l}\text { 16. May the } \\
\text { arbitrator } \\
\text { appoint experts } \\
\text { and if so, may } \\
\text { the parties: }\end{array}$ & $\begin{array}{l}\text { Yes, unless the } \\
\text { parties agree } \\
\text { otherwise: } \\
\text { Schedule II, } \\
\text { art. 26.1. }\end{array}$ & Yes: art. 14.2 . & Yes: art. 23.1. & Yes: art. 27.1. & $\begin{array}{l}\text { Yes, unless the } \\
\text { parties agree } \\
\text { otherwise: } \\
\text { art. 12.1(a). }\end{array}$ & Yes: art. $7(t)$. & Yes: r. 12.3. & Yes: s. $29(1)(a)$. \\
\hline $\begin{array}{l}\text { (a) question } \\
\text { the expert; and }\end{array}$ & $\begin{array}{l}\text { Yes, unless the } \\
\text { parties agree } \\
\text { otherwise: } \\
\text { Schedule II, } \\
\text { art. } 26.2 \text {. }\end{array}$ & $\begin{array}{l}\text { The Rules do not } \\
\text { specifically address } \\
\text { the parties' rights. } \\
\text { However, ant. } 11 \\
\text { may allow. }\end{array}$ & $\begin{array}{l}\text { Yes, at the request } \\
\text { of any party: } \\
\text { art. } 23.4 \text {. }\end{array}$ & $\begin{array}{l}\text { Yes, at the request } \\
\text { of either party: } \\
\text { ar. } 27.4 \text {. }\end{array}$ & $\begin{array}{l}\text { Yes, if a pany so } \\
\text { requests or the } \\
\text { tribunal deems is } \\
\text { necessary, unless } \\
\text { otherwise agreed } \\
\text { to by the parties: } \\
\text { art. } 12.2 \text {. }\end{array}$ & Yes? See ar, 5.9. & Yes: $\mathrm{r} .12 .3$. & $\begin{array}{l}\text { Yes, if a party } \\
\text { requests it or if the } \\
\text { tribunal considers } \\
\text { it necessary: } \\
\text { 3. } 29(6)(a) \text {. }\end{array}$ \\
\hline $\begin{array}{l}\text { (b) present } \\
\text { their own } \\
\text { exper } \\
\text { evidence? }\end{array}$ & $\begin{array}{l}\text { Yes: Schedule II, } \\
\text { ant. } 26.2 .\end{array}$ & Sume as (a) above. & $\begin{array}{l}\text { Yes, at the request } \\
\text { of any party: } \\
\text { art. 23.4. }\end{array}$ & Yes: an 27.4 . & $\begin{array}{l}\text { Yes, if a party so } \\
\text { requests or the } \\
\text { tribunal considers } \\
\text { it necessary: } \\
\text { art. } 12.2 \text {. }\end{array}$ & $\begin{array}{l}\text { No express } \\
\text { provision regarding } \\
\text { parties' rights in } \\
\text { relation to } \\
\text { arbitrator's experts, } \\
\text { but an. } 5 \text { likely } \\
\text { allows. }\end{array}$ & $\begin{array}{l}\text { No express } \\
\text { provision, although } \\
\text { r. } 12.3 \text { allows the } \\
\text { parties to rebut the } \\
\text { tribunal's experts. }\end{array}$ & $\begin{array}{l}\text { Yes, if a party } \\
\text { requests it or the } \\
\text { tribunal considers } \\
\text { it necessary: } \\
\text { s. } 29(6)(b) \text {. }\end{array}$ \\
\hline $\begin{array}{l}\text { 17. May the } \\
\text { arbitrator } \\
\text { deviate from } \\
\text { common law } \\
\text { procedures in } \\
\text { presenting } \\
\text { evidence? }\end{array}$ & $\begin{array}{l}\text { Yes. Unless the } \\
\text { parties have agreed } \\
\text { otherwise, the } \\
\text { tribunal may } \\
\text { conduct artitration } \\
\text { as it sees fit and } \\
\text { may determine the } \\
\text { admissibility, } \\
\text { relevarce, } \\
\text { materiality and } \\
\text { weight of any } \\
\text { evidence: } \\
\text { Schedule II, } \\
\text { art. 19.2. }\end{array}$ & $\begin{array}{l}\text { Yes. The arbitrator } \\
\text { may cstablish the } \\
\text { facts "by all } \\
\text { appropriate means," } \\
\text { ar. } 14.1 \text {. }\end{array}$ & $\begin{array}{l}\text { Yes. The tribunal } \\
\text { may conduct the } \\
\text { arbitration in } \\
\text { whatever manner it } \\
\text { considers } \\
\text { appropriate: } \\
\text { ant. } 16.1 \text { and may } \\
\text { deternine the } \\
\text { relevance, } \\
\text { admissibility and } \\
\text { weight of evidence. } \\
\text { art. } 21.6 \text {. }\end{array}$ & $\begin{array}{l}\text { Yes. The arbitral } \\
\text { tribunal may } \\
\text { conduct the } \\
\text { arbitration in the } \\
\text { manner it } \\
\text { considers } \\
\text { appropriate: } \\
\text { ant. } 15.1 \text { and may } \\
\text { deternine the } \\
\text { relevance, } \\
\text { admissibility and } \\
\text { weight of } \\
\text { evidence: ar. } 25.6 \text {. }\end{array}$ & $\begin{array}{l}\text { Yes. The tribunal } \\
\text { has the widest } \\
\text { discretion to } \\
\text { ensuse the just, } \\
\text { expeditious, } \\
\text { economical and } \\
\text { final determination } \\
\text { of the dispute: } \\
\text { art. } 5.2 \text {. See also } \\
\text { art. } 14.3 \text {. }\end{array}$ & $\begin{array}{l}\text { Yes: arts. } 1.2,6.2 \text {, } \\
7(\mathrm{~h}) \text { implicitly } \\
\text { allow such } \\
\text { deviation. }\end{array}$ & Yes: s. 12.2. & $\begin{array}{l}\text { Yes. The tribunal } \\
\text { may conduct the } \\
\text { arbitration in } \\
\text { whatever manner it } \\
\text { considers } \\
\text { appropriate: } \\
\text { s. 19(2). It may } \\
\text { also determine } \\
\text { admissibility. } \\
\text { weight and } \\
\text { relevance of the } \\
\text { evidence: s. } 19(3) \text {. }\end{array}$ \\
\hline
\end{tabular}




\begin{tabular}{|c|c|c|c|c|c|c|c|c|}
\hline \multirow[t]{2}{*}{ QUESTION } & \multicolumn{8}{|c|}{ ANSWERS } \\
\hline & $\begin{array}{l}\text { Alberte International } \\
\text { Commerciel } \\
\text { Arbitretion Aat }\end{array}$ & $\begin{array}{l}\text { Intermational Chumber } \\
\text { of Commerce Rules } \\
\text { (ICC) }\end{array}$ & $\begin{array}{l}\text { American Arbitration } \\
\text { Ansociation } \\
\text { International } \\
\text { Arbitration Rulas } \\
\text { (MU) }\end{array}$ & $\begin{array}{l}\text { UNCTTRAL } \\
\text { Afblitration Rutien, } \\
1976\end{array}$ & $\begin{array}{l}\text { Losden Coust of } \\
\text { Internallonel } \\
\text { Arbltration Rules } \\
\text { (LC1A) }\end{array}$ & $\begin{array}{l}\text { Intermational Bar } \\
\text { Assocdation } \\
\text { Supplementery Rules } \\
\text { (IBA) }\end{array}$ & $\begin{array}{l}\text { CPR loutituse for } \\
\text { Dispuse Resoletion } \\
\text { Model ADR } \\
\text { Proceduse }\end{array}$ & $\begin{array}{l}\text { Britlsh Cotumbla } \\
\text { Intermational } \\
\text { Commerdel } \\
\text { Arbitzation Centre } \\
\text { (BCICAC) }\end{array}$ \\
\hline $\begin{array}{l}\text { 18. May an } \\
\text { arbitrator order } \\
\text { witnesses to } \\
\text { appear? }\end{array}$ & $\begin{array}{l}\text { No express } \\
\text { mention of } \\
\text { witnesses beyond } \\
\text { experts. However, } \\
\text { the tribunal or a } \\
\text { pany with the } \\
\text { tribunal's approval } \\
\text { may request cour } \\
\text { assistance in taking } \\
\text { evidence: } \\
\text { Schedule II. } \\
\text { ar. } 27 \text {. }\end{array}$ & $\begin{array}{l}\text { Yes, provided the } \\
\text { parties are present } \\
\text { or have been duly } \\
\text { summoned: } \\
\text { art. 14.2. }\end{array}$ & $\begin{array}{l}\text { No express } \\
\text { provision. } \\
\text { (an. } 21.4 \text { only } \\
\text { allows the arbitrator } \\
\text { to determine the } \\
\text { "manner" in which } \\
\text { witnesses are } \\
\text { examined.) }\end{array}$ & $\begin{array}{l}\text { No express } \\
\text { provision. } \\
\text { (ant. } 25.4 \text { only } \\
\text { allows the } \\
\text { arbitrator to } \\
\text { determine the } \\
\text {-manner in which } \\
\text { witnesses are } \\
\text { examined.) }\end{array}$ & $\begin{array}{l}\text { Yes, whether } \\
\text { witnesses of fact } \\
\text { or expert } \\
\text { witnesses: } \\
\text { art. } 11.2 \text {. Parties } \\
\text { may also request: } \\
\text { ant } 11.4 \text {. }\end{array}$ & Yes: ant. 5.6. & $\begin{array}{l}\text { No express } \\
\text { provision, but } r \text {. } \\
12.3 \text { may allow, as } \\
\text { it states that the } \\
\text { abitrator "may } \\
\text { require the parties } \\
\text { to produce } \\
\text { evidence in } \\
\text { addition to that } \\
\text { initially offered". }\end{array}$ & $\begin{array}{l}\text { No express } \\
\text { provision, although } \\
\text { s. } 25(3) \text { allows the } \\
\text { arbitrator to order } \\
\text { documents "or } \\
\text { other evidence" be } \\
\text { produced. (s. } 27(2) \\
\text { allows the } \\
\text { arbitrator to } \\
\text { deternine the } \\
\text { manner in which } \\
\text { witnesses are } \\
\text { examined.) }\end{array}$ \\
\hline $\begin{array}{l}\text { 19. Must the } \\
\text { asbitrator take } \\
\text { into account } \\
\text { usages of trade? }\end{array}$ & $\begin{array}{l}\text { Yes: Schedule II, } \\
\text { art. 28.4. }\end{array}$ & Yes: art. 13.5. & Yes: art. 29.2. & Yes: art. 33.3 . & $\begin{array}{l}\text { No express } \\
\text { provision. }\end{array}$ & $\begin{array}{l}\text { No express } \\
\text { provision. }\end{array}$ & Yes: t. 10.2. & Yes: s. 30(5). \\
\hline $\begin{array}{l}\text { 20. Must the } \\
\text { arbitrator give } \\
\text { reasons for the } \\
\text { award? }\end{array}$ & $\begin{array}{l}\text { Yes, unless the } \\
\text { parties agree } \\
\text { otherwise: } \\
\text { Schedule II, } \\
\text { ant. } 31.2 \text {. }\end{array}$ & $\begin{array}{l}\text { No express } \\
\text { provision, but } \\
\text { awards must be } \\
\text { submitted to the } \\
\text { institution, which } \\
\text { may draw the } \\
\text { arbitrator's antention } \\
\text { to points of } \\
\text { substance: art. } 21 \text {. }\end{array}$ & $\begin{array}{l}\text { Yes: ar. 28.2, } \\
\text { unless the parties } \\
\text { agree otherwise, or } \\
\text { unless the award is } \\
\text { the result of a } \\
\text { settlement: } \\
\text { art. } 30.1 \text {. }\end{array}$ & $\begin{array}{l}\text { Yes, unless the } \\
\text { parties agree } \\
\text { otherwise: } \\
\text { art. } 32.3 \text {, or unless } \\
\text { the award is the } \\
\text { result of a } \\
\text { settlement: } \\
\text { art. } 34.1 \text {. }\end{array}$ & $\begin{array}{l}\text { Yes, unless the } \\
\text { parties agree } \\
\text { otherwise: } \\
\text { art. 16.1. }\end{array}$ & $\begin{array}{l}\text { No express } \\
\text { provision. }\end{array}$ & $\begin{array}{l}\text { Yes, unless the } \\
\text { parties agrec } \\
\text { otherwise: r. 14.2. }\end{array}$ & $\begin{array}{l}\text { Yes, unless the } \\
\text { award is the result } \\
\text { of a setrlement: } \\
\text { 3. 34(4). }\end{array}$ \\
\hline
\end{tabular}




\begin{tabular}{|c|c|c|c|c|c|c|c|c|}
\hline \multirow[t]{2}{*}{ QUESTION } & \multicolumn{8}{|c|}{ ANSWERS } \\
\hline & $\begin{array}{l}\text { Aberta Insernetionel } \\
\text { Commercial } \\
\text { Arbieretion Aat }\end{array}$ & $\begin{array}{l}\text { Intermetsonal Chamber } \\
\text { of Commerce Rultet } \\
\text { (ICC) }\end{array}$ & $\begin{array}{l}\text { American Arbismoston } \\
\text { Association } \\
\text { International } \\
\text { Asblitration Rulles } \\
\text { (AMA) }\end{array}$ & $\begin{array}{l}\text { UNCTrRAL } \\
\text { Arbltration Rules, } \\
1976\end{array}$ & $\begin{array}{l}\text { Londos Cours of } \\
\text { tinternational } \\
\text { Asbitratlon Rutes } \\
\text { (LCIA) }\end{array}$ & $\begin{array}{l}\text { Internatioral Bar } \\
\text { Assoctation } \\
\text { Supplementury Rulet } \\
\text { (IBA) }\end{array}$ & $\begin{array}{l}\text { CPR Institute for } \\
\text { Dlapute Resolution } \\
\text { Model ADR } \\
\text { Procedure }\end{array}$ & $\begin{array}{l}\text { British Columbis } \\
\text { Internationsl } \\
\text { Commeredel } \\
\text { Artitration Centre } \\
\text { (BCiCAC) }\end{array}$ \\
\hline $\begin{array}{l}\text { 21. Is a } \\
\text { majority } \\
\text { decision } \\
\text { required, or } \\
\text { may the chair } \\
\text { decide, in the } \\
\text { absence of a } \\
\text { majority? }\end{array}$ & $\begin{array}{l}\text { Unless the parties } \\
\text { agree otherwise, a } \\
\text { majority is } \\
\text { required. } \\
\text { However, } \\
\text { questions of } \\
\text { procedure may be } \\
\text { decided by the } \\
\text { chair, if so } \\
\text { authorized by the } \\
\text { parties or all } \\
\text { members of the } \\
\text { tribunal: } \\
\text { Schedule Il, } \\
\text { ar. } 29 \text {. }\end{array}$ & $\begin{array}{l}\text { A majority is } \\
\text { nomally required, } \\
\text { but if there is no } \\
\text { majority, the chair } \\
\text { of the tribunal may } \\
\text { decide alone: } \\
\text { art. } 19 .\end{array}$ & $\begin{array}{l}\text { A majority is } \\
\text { required for any } \\
\text { "award, decision or } \\
\text { ruling": ar. } 27.1 \text {. } \\
\text { However, the } \\
\text { parties may } \\
\text { authorize the chair } \\
\text { to make procedural } \\
\text { nelings, subject to } \\
\text { revision by the } \\
\text { tribunal: art. } 27.2 \text {. }\end{array}$ & $\begin{array}{l}\text { A majority is } \\
\text { required for any } \\
\text { "award or other } \\
\text { decision": } \\
\text { art. } 31.1 \text {. } \\
\text { However, on } \\
\text { questions of } \\
\text { procedure, the } \\
\text { chair may decide } \\
\text { subject to any } \\
\text { revisions by the } \\
\text { tribunal: art. } 31.2 \text {. }\end{array}$ & $\begin{array}{l}\text { A majority is } \\
\text { required, but the } \\
\text { chair of the } \\
\text { tribunal may make } \\
\text { the award alone if } \\
\text { a majority is not } \\
\text { possible: art. } 16.3 \text {. } \\
\text { The chair may also } \\
\text { make procedura! } \\
\text { rulings alone after } \\
\text { consulting the } \\
\text { other arbitrators: } \\
\text { art. 5.3. }\end{array}$ & $\begin{array}{l}\text { No express } \\
\text { provision. }\end{array}$ & $\begin{array}{l}\text { Unless the partics } \\
\text { agree otherwise, a } \\
\text { majority is } \\
\text { required. } \\
\text { However, if an } \\
\text { award consists of } \\
\text { two or more parts, } \\
\text { it is sufficient if } \\
\text { any two out of } \\
\text { three arbitrators } \\
\text { approve each part, } \\
\text { even if the same } \\
\text { two arbitrators do } \\
\text { not approve each } \\
\text { part: } r \text {. } 14.2 \text { and } \\
\text { commentary. }\end{array}$ & $\begin{array}{l}\text { A majority is } \\
\text { required, but } \\
\text { procedural } \\
\text { questions may be } \\
\text { decided by the } \\
\text { chair. ss. 32(1). } \\
32(2) \text {. Reasons } \\
\text { must be provided } \\
\text { by any abitrators } \\
\text { not signing the } \\
\text { award: 3. 34(3). }\end{array}$ \\
\hline $\begin{array}{l}\text { 22. Is recourse } \\
\text { to the courts } \\
\text { against the } \\
\text { award } \\
\text { prohibited? }\end{array}$ & $\begin{array}{l}\text { Generally, yes, } \\
\text { unless such } \\
\text { recourse is } \\
\text { specifically } \\
\text { provided for: } \\
\text { Schedule II, art. } 5 \text {. } \\
\text { In particular, } \\
\text { Schedule II. } \\
\text { erts. } 34.1,34.2 \text { set } \\
\text { out a number of } \\
\text { grounds upon } \\
\text { which parties may } \\
\text { have recourse to } \\
\text { the courts against } \\
\text { an arbitral award. }\end{array}$ & $\begin{array}{l}\text { Yes: All awards are } \\
\text { final and may not be } \\
\text { appealed: art. } 24 \text {. }\end{array}$ & $\begin{array}{l}\text { Implicitly, yes. } \\
\text { ant. } 28 \text { states that } \\
\text { awards are "final } \\
\text { and binding" and } \\
\text { obliges the parties } \\
\text { to carry out the } \\
\text { award without } \\
\text { delay. Although } \\
\text { art. } 31.1 \text { allows the } \\
\text { parties to request } \\
\text { that the tribunal } \\
\text { interpret of correct } \\
\text { technical errors or } \\
\text { make an additiona! } \\
\text { atward, no express } \\
\text { reference is made } \\
\text { to the cours. }\end{array}$ & $\begin{array}{l}\text { Probably. art. } 32.2 \\
\text { states that the } \\
\text { award is final and } \\
\text { binding. Although } \\
\text { arts. } 35,36 \text { and } 37 \\
\text { allow the parties to } \\
\text { request that the } \\
\text { arbitrator interpret } \\
\text { or correct the } \\
\text { award, or make an } \\
\text { additional award, } \\
\text { no express } \\
\text { reference is made } \\
\text { to the courts. }\end{array}$ & $\begin{array}{l}\text { Yes. The parties } \\
\text { waive their right to } \\
\text { any form of appeal } \\
\text { of recourse to the } \\
\text { courts: art. 16.8. } \\
\text { See also arts. 3.9, } \\
13.2 \text { and } 15.3 \text {. } \\
\text { (Corrections and } \\
\text { additional awards } \\
\text { may be requested } \\
\text { from the tribunal: } \\
\text { art. 17.) }\end{array}$ & $\begin{array}{l}\text { No express } \\
\text { provision. }\end{array}$ & $\begin{array}{l}\text { The tribunal may } \\
\text { decide, by stating } \\
\text { in its award, } \\
\text { whether it views } \\
\text { the award as final } \\
\text { for the purposes of } \\
\text { judicial } \\
\text { proceedings: } \\
\text { r. 14.1. However, } \\
\text { r. } 14.6 \text { provides } \\
\text { that } 30 \text { days after } \\
\text { the award is } \\
\text { delivered, it } \\
\text { becomes final and } \\
\text { binding, and the } \\
\text { parties must carry } \\
\text { it out without } \\
\text { delay. }\end{array}$ & $\begin{array}{l}\text { No express } \\
\text { provision. }\end{array}$ \\
\hline
\end{tabular}




\begin{tabular}{|c|c|c|c|c|c|c|c|c|}
\hline \multirow[t]{2}{*}{ QUESTION } & \multicolumn{8}{|c|}{ ANSWERS } \\
\hline & $\begin{array}{l}\text { Alberts Infornetional } \\
\text { Comomercial } \\
\text { Avbitretion Act }\end{array}$ & $\begin{array}{l}\text { Insermational Chasmber } \\
\text { of Commeree Rustes } \\
\text { (CC) }\end{array}$ & 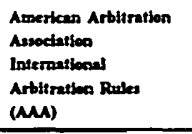 & $\begin{array}{l}\text { UNCTTRAL } \\
\text { Arbitration Ruslea, } \\
\text { Int6 }\end{array}$ & $\begin{array}{l}\text { London Coust of } \\
\text { Internatlonal } \\
\text { Arbitrallon Reules } \\
\text { (LCIA) }\end{array}$ & $\begin{array}{l}\text { Lsternational Bor } \\
\text { Aesodestion } \\
\text { Supplementary Rusles } \\
\text { (ABA) }\end{array}$ & $\begin{array}{l}\text { CPR Instituse for } \\
\text { Dlupule Resolution } \\
\text { Moded ADR } \\
\text { Procedere }\end{array}$ & 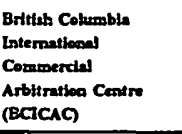 \\
\hline $\begin{array}{l}\text { 23. Which } \\
\text { conflict of laws } \\
\text { rules, if any. } \\
\text { apply if the } \\
\text { parties fail to } \\
\text { specify the law } \\
\text { applicable to } \\
\text { the substance of } \\
\text { the dispute? }\end{array}$ & $\begin{array}{l}\text { No specific } \\
\text { conflict of laws } \\
\text { rules necesarily } \\
\text { apply. The } \\
\text { tribunal may apply } \\
\text { the rules of law it } \\
\text { considers } \\
\text { appropriate: } 3.7 \text {. } \\
\text { See also } \\
\text { Schedule II, } \\
\text { ar. } 28(2) \text {. }\end{array}$ & $\begin{array}{l}\text { The arbitrator shall } \\
\text { apply the law } \\
\text { designated as the } \\
\text { proper law by the } \\
\text { nule of conflict } \\
\text { which he deems } \\
\text { appropriatc: } \\
\text { ar. 13.3. }\end{array}$ & $\begin{array}{l}\text { No specific conflict } \\
\text { of laws nutes } \\
\text { necesarily apply. } \\
\text { The tribunal may } \\
\text { apply such law(s) } \\
\text { as it deems } \\
\text { apptopriate: } \\
\text { ar. } 29.1 \text {. }\end{array}$ & $\begin{array}{l}\text { The tribunal shall } \\
\text { apply the law } \\
\text { determined by the } \\
\text { conflict of laws } \\
\text { rules it considers } \\
\text { appropriate: } \\
\text { art. 33.1. }\end{array}$ & $\begin{array}{l}\text { No specific } \\
\text { conflict of laws } \\
\text { rules necessarily } \\
\text { apply. The } \\
\text { arbitrator, after } \\
\text { giving the parties a } \\
\text { proper opportunity } \\
\text { to state their } \\
\text { views, may } \\
\text { determine the rules } \\
\text { of law applicable: } \\
\text { art. } 13.1 \text { (a). }\end{array}$ & $\begin{array}{l}\text { No express } \\
\text { provision, although } \\
\text { ars. } 1.2,6.2,7(\mathrm{~h}) \\
\text { likely allow the } \\
\text { arbitrator to apply } \\
\text { whichever law is } \\
\text { deemed } \\
\text { appropriate, } \\
\text { without having to } \\
\text { necessarily } \\
\text { consider any } \\
\text { specific connict of } \\
\text { laws nales. }\end{array}$ & $\begin{array}{l}\text { No specific } \\
\text { conflict of laws } \\
\text { rules necessarily } \\
\text { apply. The } \\
\text { tribunal shall apply } \\
\text { such law(s) as it } \\
\text { determines } \\
\text { appropriate: } \\
\text { r. 10.1. }\end{array}$ & $\begin{array}{l}\text { No specific } \\
\text { conflict of laws } \\
\text { nules necessarily } \\
\text { apply. The } \\
\text { tribunal shall apply } \\
\text { such law(s) as it } \\
\text { deternines } \\
\text { appropriate, given } \\
\text { all the } \\
\text { circumstances: } \\
\text { s. } 30(3) \text {. Sec also } \\
\text { s. } 30(2) \text {. }\end{array}$ \\
\hline $\begin{array}{l}\text { 24. Is recourse } \\
\text { to the courts } \\
\text { possible based } \\
\text { on: } \\
\text { a) breaches of } \\
\text { natural justice } \\
\text { b) bias of } \\
\text { arbitrator } \\
\text { c) errors of } \\
\text { law? }\end{array}$ & $\begin{array}{l}\text { Yes, if } \\
\text { composition of the } \\
\text { atbitral tribunal or } \\
\text { arbitral procedure } \\
\text { was not in } \\
\text { accordance with } \\
\text { this Law - or if } \\
\text { the agreement was } \\
\text { not valid undes the } \\
\text { law: Schedule II, } \\
\text { an. } 34.2 \text {. }\end{array}$ & $\begin{array}{l}\text { No express } \\
\text { provision. }\end{array}$ & $\begin{array}{l}\text { No express } \\
\text { provision. }\end{array}$ & $\begin{array}{l}\text { No express } \\
\text { provision. }\end{array}$ & $\begin{array}{l}\text { No. In fact, by } \\
\text { agrecing to the } \\
\text { athitration the } \\
\text { parties have not } \\
\text { agreed to apply to } \\
\text { any coun of law } \\
\text { for certain types of } \\
\text { orders: art. 13.2. }\end{array}$ & $\begin{array}{l}\text { No express } \\
\text { provision. }\end{array}$ & $\begin{array}{l}\text { No express } \\
\text { provision. }\end{array}$ & $\begin{array}{l}\text { No express } \\
\text { provision. }\end{array}$ \\
\hline
\end{tabular}




\begin{tabular}{|c|c|c|c|c|c|c|c|c|}
\hline \multirow[t]{2}{*}{ QUESTION } & \multicolumn{8}{|c|}{ ANSWERS } \\
\hline & $\begin{array}{l}\text { Abserte International } \\
\text { Comomerciat } \\
\text { Arbicretion Aet }\end{array}$ & $\begin{array}{l}\text { Intermational Chassber } \\
\text { of Commerce Rusea } \\
\text { (ICC) }\end{array}$ & 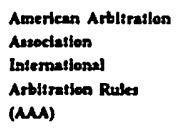 & $\begin{array}{l}\text { UNCTTRAL } \\
\text { Arblitration Rules, } \\
1976\end{array}$ & $\begin{array}{l}\text { Londos Court of } \\
\text { Intematlossal } \\
\text { Arbltration Rules } \\
\text { (LCIA) }\end{array}$ & $\begin{array}{l}\text { Internationsy Bar } \\
\text { Assoctation } \\
\text { Supplementany Rules } \\
\text { (IBA) }\end{array}$ & $\begin{array}{l}\text { CPR Inatisuse for } \\
\text { Dispuse Resolution } \\
\text { Modes ADR } \\
\text { Procaduse }\end{array}$ & $\begin{array}{l}\text { Brttes Columbia } \\
\text { tonternations] } \\
\text { Comanerdin! } \\
\text { Arbitration Centre } \\
\text { (BCICAC) }\end{array}$ \\
\hline $\begin{array}{l}\text { 25. May } \\
\text { different } \\
\text { arbitrations be } \\
\text { consolidated? }\end{array}$ & $\begin{array}{l}\text { The Court of } \\
\text { Queen's Bench on } \\
\text { application of the } \\
\text { paries to two or } \\
\text { more arbitration } \\
\text { proceedings may } \\
\text { order that they be } \\
\text { consolidated, heard } \\
\text { at the same time or } \\
\text { that any of them } \\
\text { be stayed pending } \\
\text { any of the others: } \\
\text { s. } 8 \text {. }\end{array}$ & $\begin{array}{l}\text { No express } \\
\text { provision allowing } \\
\text { consolidation. }\end{array}$ & $\begin{array}{l}\text { No express } \\
\text { provision allowing } \\
\text { consolidation. }\end{array}$ & $\begin{array}{l}\text { No express } \\
\text { provision allowing } \\
\text { consolidation. }\end{array}$ & $\begin{array}{l}\text { Yes, with the } \\
\text { parties' express } \\
\text { consent and after } \\
\text { giving the parties a } \\
\text { proper opportunity } \\
\text { to state their } \\
\text { views: } \\
\text { art. } 13.1 \text { (c). }\end{array}$ & $\begin{array}{l}\text { No express } \\
\text { provision allowing } \\
\text { consolidation. }\end{array}$ & $\begin{array}{l}\text { No express } \\
\text { provision allowing } \\
\text { consolidation. }\end{array}$ & $\begin{array}{l}\text { No express } \\
\text { provision allowing } \\
\text { consolidation. }\end{array}$ \\
\hline
\end{tabular}




\section{SCHEDULE II}

\section{DISPUTE RESOLUTION *}

\section{Section 0.1 Disputes - Negotiation; Mediation:}

(a) In the event of any dispute, controversy or claim (a "Dispute") arising out of or relating to this Agreement or any related agreement or subcontract specifically referred to in this Agreement, or the performance, non-performance, breach, termination, or invalidity ${ }^{116}$ hereof or thereof, [exceptions, if any], the Dispute shall be the subject of an attempt at an amicable solution, for which purpose any Party ${ }^{117}$ may give notice to the other Parties, giving a concise description of the Dispute, the position of such Party in respect thereof and proposing a meeting among [the chief executive officers; other] or their designees (the "Senior Officers"), [of the Parties or ultimate parent companies the Parties] each of whom shall be at a higher level of management than the persons who have direct responsibility for the administration of this Agreement. Such meeting shall be held in [place] (or such other place as the Parties may agree) for the purpose of resolving the Dispute. Within 15 days after delivery of the notice, each receiving Party shall submit to the other Parties a written response, setting forth the position of the receiving party in respect of the Dispute.

(b) If such a meeting is called, the meeting shall take place within 30 days of its being requested. If such meeting does not take place within such 30 days or if within 15 days after such meeting the Senior Officers have not resolved the Dispute, then the Dispute shall, upon the written request of any Party be referred to mediation in accordance with subsection (c) hereof or, failing any such request, settled by arbitration in accordance with the remaining provisions of this Article. ${ }^{118}$

(c) If a party requests that a Dispute be referred to mediation, there shall be one qualified, experienced mediator who shall be impartial and shall be independent of and have had no financial connection with any Party. Should the services of an appointing

- These provisions were drafted by M.A. Hurst, a partner of the law firm of Milner Fenerty. They represent the writer's attempt to draft to the matters discussed in the body of the article by E.D.D. Tavender, Q.C. and to facilitate discussion of those matters. These provisions are not intended to be encyclopedic and will not be appropriate in all circumstances. The writer gratefully acknowledges the assistance of E.D.D. Tavender, A.G. MacWilliam and S.M.H. Wakil, each of Milner Fenerty's Calgary office. This draft is for discussion purposes only. See Section 0.21.

The term "Party(ies)" is used in s. 0.1 to refer to parties to the Agreement which contains the arbitration provisions. In the remaining sections, "Party(ies)" refers to parties to the Dispute.

It is not uncommon for parties to stipulate the holding of a non-binding mediation with a qualified, neutral third party as a pre-condition to arbitration or litigation. Mediation can be additional to or in lieu of a Senior Officers' Meeting. Mediation obviously adds a potential level of cost but can in appropriate cases better assist the parties in reaching an early resolution of the dispute than a Senior Officers' Meeting. Parties should weigh the potential benefits of mediation and include a mediation clause where appropriate. 
authority be necessary, the appointing authority shall be [specify authority]. ${ }^{119}$ The Parties shall have 15 days from the date of the request for mediation to agree among themselves on the appointment of the mediator. If, after such 15 day period, the parties have not agreed on such appointment, the appointing authority shall appoint the mediator. The mediator may not serve as an arbitrator in any arbitration of the Dispute. The [stipulate mediation procedure] ${ }^{120}$ shall apply to mediations conducted pursuant to this subsection.

(d) All negotiations, including any offers of settlement or compromise, undertaken pursuant to this Section shall be on a "without prejudice" basis and shall not be admissible in any subsequent arbitration or other proceeding.

\section{Section 0.2 Referral to Arbitration; Rules:}

If a Dispute remains unresolved after the application of the procedures referred to in Section 0.1 , then after the expiration of the 30 day or 15 day period (as the case may be) referred to in subsection $0.1(b)$, such Dispute:

(a) if it involves a claim in excess of [specify dollar amount] or arises under Section [stipulate any provisions of the agreement under which Disputes might arise which are to be resolved by arbitration pursuant to this Article] of this Agreement may be referred by any Party (the "Claimant") to arbitration in accordance with the provisions of this Article. ${ }^{121}$ The arbitration shall be conducted under the Arbitration Rules [define as UNCITRAL Arbitration Rules or UNCITRAL Model Law or other set of rules] ${ }^{122}$ as they read on the date of this Agreement except to the extent that the rules are inconsistent with or in conflict with any terms of this Article, in which event such terms of this Article shall prevail. The arbitration shall be the sole and exclusive forum for resolution of the Dispute. Judgment on the arbitral award may be entered by any court having jurisdiction over a Party or any of a Party's assets; ${ }^{123}$

Before choosing an appointing authority, parties should investigate issues of cost, the experience and track record of potential appointing authorities. Appointing authorities may include organizations such as the Centre for Public Resources (CPR) Institute for Dispute Resolution, a nonprofit organization based in New York City.

Some international arbitration rules provide for mediation or conciliation procedures. See e.g. "Rules for Optional Conciliation," in ICC Rules, arts. 1-11; Part 6 of the Rules for International Commercial Arbitration and Conciliation Proceedings in the BCICAC Rules.

This set of arbitration provisions has been prepared to illustrate how the matters respecting procedural and substantive faimess raised in the Paper might be "drafted to."

The UNCITRAL Arbitration Rules are, in the view of some writers, the favoured choice among North American parties opting for international arbitration as their dispute resolution mechanism. Parties may wish to use another set of rules or to opt for an "institutional" arbitration. However, a decision not to incorporate any rules will leave the drafter with the task of fashioning a complete code for the governing of the procedure, without a "safety net." the award might be sought should be identified in advance and the advice of counsel in such jurisdictions should be obtained prior to finalizing the arbitration provisions. 
(b) if it involves a claim under [specify amount], may be referred by any Party (the "Claimant") to arbitration conducted under the Arbitration Rules, unmodified by the remaining provisions of this Article. ${ }^{124}$

\section{Section 0.3 Arbitral Tribunal; Number and Appointment of Arbitrators; Challenges; Failure or Inability to Act:}

(a) There shall be [one] arbitrator [the "Tribunal," of which individual members are "Arbitrator(s)"], ${ }^{125}$ who shall be impartial and shall be independent of and have had no financial connection with any Party. Should the services of an appointing authority be necessary, the appointing authority shall be [specify authority]. ${ }^{126}$ The Parties shall have 30 days to agree among themselves on the appointment of the Tribunal. If, after such 30-day period, the Parties have not agreed on such appointment, the appointing authority shall appoint the Tribunal.

(b) Absent consent of all Parties, no Arbitrator may be a national of a country of which any of the Parties is a national. Any person serving as an Arbitrator ${ }^{127}$ shall have training or experience in serving as an arbitrator, and shall have legal training [and/or] experience as a practicing lawyer in [the situs of the arbitration]. ${ }^{128}$

The provisions in (a) and (b) above are provided by way of example only. Consideration should be given to whether different dispute resolution methods should be applied to different disputes. Use of monetary thresholds may cause unnecessary litigation over the applicable method of dispute resolution and the tribunal's jurisdiction.

The designation of a single legally trained arbitrator is preferable to the appointment of three arbitrators, especially where the three arbitrator panel is expected to have, in effect, one arbitrator advocating the cause of each side and a third "umpiring" arbitrator. While such arbitral panels are common in labour and other disputes even in an arbitral proceeding where concerns of faimess are paramount, one adversarial proceeding, rather than two, is sufficient.

Before making their choice, parties should investigate issues of cost and should also inquire into the track record of potential appointing authorities in appointing suitable arbitrators. Potential choices will generally include arbitral institutions such as the American Arbitration Association or the Court.

Both the UNCITRAL Arbitration Rules and the UNCITRAL Model Law provide for challenges to the arbitrator. The former states lack of impartiality or independence to be the only grounds for removal, whereas the latter contemplates challenge on the basis of insufficient qualifications, where such qualifications are the subject matter of agreements between the Parties. The UNCITRAL Model Law provides a useful set of grounds for challenge and challenge procedure (arts. 12,13). These, or similar provisions, could be incorporated into the draft at this point in circumstances where the Parties are not incorporating the Arbitration Rules or the Model Law by reference. Challenges to the appointment of the arbitrator, particularly where founded on questions of independence or impartiality are best referred to the appropriate court of superior jurisdiction in the situs of the arbitration and not to the arbitrator, as is sometimes provided.

The situs of the arbitration should, wherever possible, be the jurisdiction of the proper law of the contract. The requirement for arbitral experience and/or legal training is most appropriate where issues of faimess and decisions being rendered strictly in accordance with law are paramount. In other kinds of arbitrations, for instance those where the parties will seek a person of specific, nonlegal technical or professional expertise, arbitral experience will still be desirable. However, the requirement for legal training may have to be dispensed with, as the parties in such cases are relying on the arbitrator's non-legal technical knowledge. 


\section{Section 0.4 Place and Language of Arbitration: ${ }^{129}$}

The place of arbitration shall be [location].$^{130}$ The arbitration shall be conducted in the English language and any foreign-language documents presented at such arbitration shall be accompanied by an English translation thereof.

\section{Section 0.5 Applicable Law:}

The Tribunal shall apply the laws of [proper law of contract] without regard to the principles of conflicts of laws. All matters of procedure, including the making of any interim orders, shall be resolved in accordance with the laws of [law of the situs of the arbitration, which should be the same as the law of the jurisdiction of the Specified Court - use proper law of the contract, if possible].

\section{Section 0.6 Claims Giving Rise to Multi-Party Proceedings: ${ }^{131}$}

Unless the Parties agree otherwise, the arbitration provisions of this Agreement shall terminate if any Party advances or is required to respond to any other legitimate claim not covered by Sections $0.2-0.22$ of this Agreement, providing that such other claim arises out of substantially the same facts or subject matter as the Dispute governed by this Agreement and could reasonably give rise to contribution, indemnity, duplicative or inconsistent remedies or relief. [The Tribunal shall be empowered to determine whether any such other claim falls within the contemplation of this Section 0.6].

Fairness and familiarity of procedure for Canadian parties suggests that the situs should be an English-speaking common law jurisdiction. See the comments in Part V.A regarding English rules and procedures which suggest that where judicial activism is desirable, England might be considered as the situs and English law might be the best choice for governing the proceedings. Both the UNCITRAL Arbitration Rules and the UNCITRAL Model Law allow the Tribunal to meet at a place other than the place of arbitration. Art. 16(3) of the UNCITRAL Arbitration Rules allows the Tribunal to meet at any place it "deems" appropriate, for the purpose of inspecting property or documents. Query whether this would allow the tribunal to hold oral hearings outside the place of arbitration, or whether the parties may agree otherwise. Art. 16(4) requires that the award be made at the place of arbitration. The UNCITRAL Model Law is somewhat broader and, unless the parties agree otherwise, allows the Tribunal to meet at any place it considers appropriate for the same purposes as stipulated in the UNCITRAL Arbitration Rules. The Model Law, however, also allows the Tribunal to meet in such places for the hearing of witnesses, experts and parties. Art. 31 deems the award to be made at the place of arbitration specified by the parties.

Although some authors suggest that all parties in a series of related contracts may wish to include provisions in each of the contracts allowing arbitration against any of the other parties, others point out that consolidated arbitrations often create more problems than they solve. (See e.g. Mustill \& Boyd, supra note 9 at 141 and Redfern \& Hunter, supra note 2 at 190). Parties may wish to provide for consolidation, however, if the Parties to the arbitration clause share a number of related contracts in which no other parties are involved. Section 8 of the $A I C A A$ allows the court to order consolidation. 


\section{Section 0.7 Non-Arbitrable Matters:}

Any matter expressed in this Agreement to be a matter for review, collaboration, consultation, consent, decision or agreement by the Parties or any of them shall not constitute a Dispute to be referred to or settled by arbitration proceedings pursuant to this Article or otherwise.

\section{Section 0.8 Attornment; Enforcement:}

All Parties hereby submit to the exclusive jurisdiction of (the "Specified Court") [a court of superior jurisdiction in the situs of the arbitration] in any action, suit or proceedings with respect to the enforcement of the provisions of Sections $0.2-0.22$ of this Agreement and the [non-exclusive] jurisdiction of such court with respect to the enforcement of any award thereunder. Each Party irrevocably appoints the agent for service specified opposite its name in Section [specific] ${ }^{132}$ as its authorized agent upon which process may be served in any proceeding under this Article, and agrees that service of process upon such agent, and written notice of said service to such Party, by the person serving the same to the address provided in Section [specific], shall be deemed in every respect effective service of process upon such Party in any such action, suit or proceeding. All Parties further agree to take any and all action as may be necessary to maintain such designation and appointment of such agent in full force and effect for the duration of this Agreement and to promptly advise the other Parties in writing of any unavoidable change of agent or address of agent along with the identity and address of its new agent as required.

\section{Section 0.9 Commencement of Arbitration Proceedings: ${ }^{133}$}

(a) The Claimant shall serve upon the other Party(ies) (the "Respondents") a notice of Arbitration. Proceedings are deemed to commence on the date on which a notice of arbitration is served upon the last Respondent.

(b) Unless the statement of claim was contained in the notice of arbitration, the Claimant shall serve its statement of claim in writing to the Tribunal and the Respondents within [set number] days of commencement of the arbitration proceedings.

Generally, a corporate agent should be used (there are companies which provide such services) to avoid issues arising out of the death or incapacity of individuals. A "successor" agent should also be provided for in the event of the specified agent going out of business. The agents, and their addresses, should be identified in the "Notices" provision of the Agreement.

These provisions are similar to the UNCITRAL Arbitration Rules, arts. 3, 18, 19 and the UNCITRAL Model Law, arts. 21, 23, which provide for the filing of pleadings. The drafter should refer to the UNCITRAL Arbitration Rules for further elaboration on the requirements of each of the pleadings. Art. 20 of the UNCITRAL Arbitration Rules and art. 23(2) of the UNCITRAL Model Law outline the process for amendments to pleadings. Neither the Arbitration Rules nor the Model Law require parties to append documents to their pleadings, although both allow it. 
(c) Within [set number] days of receiving the statement of claim, each Respondent shall serve its statement of defence in writing to the Tribunal, the Claimant and the other Respondents if any. The statement of defence shall reply to the particulars of the statement of claim. In its statement of defence, or at a later stage in the arbitral proceedings, if the Tribunal decides that the delay was justified in the circumstances [by extraordinary circumstances], any Respondent may make a counter-claim arising out of the same facts as the claim or rely on a claim arising out of the same facts as the claim for the purpose of a set-off.

(d) Within [set number] days of being served with the statement(s) of defence, the Claimant shall serve a written rebuttal to any counter-claim(s) by any of the Respondent(s) upon the Tribunal and all Respondents.

(e) Within [set number] days of being served with the Claimant's rebuttal, the counter-claiming Respondents, if any, may serve upon the Tribunal, the Claimant, and all other Respondents a written surrebuttal in reply to the Claimant's rebuttal.

(f) Each of the Claimant and the Respondents shall fully disclose and completely append to its Pleadings a summary of all material facts and evidence upon which it intends to rely, in accordance with the Arbitration Rules, ${ }^{134}$ including the following:

(i) a copy of the agreement(s) and all amendments thereto out of which the Dispute arises including this Article;

(ii) a list of all documents, which shall be identified by the parties thereto, date and subject matter thereof;

(iii) copies of any expert reports intended to be relied upon; and

(iv) a list of all witnesses intended to be relied upon, including names, addresses, employment and, where appropriate, the qualifications of the witnesses, and a summary of the material testimony of each such witness.

(g) The documents filed pursuant to this Section shall be referred to as the "Pleadings." The Pleadings may only be supplemented with leave of the Tribunal which shall be granted only in exceptional circumstances.

\section{Section 0.10 Preliminary Conference:}

[Set number] days after the last of the Pleadings has been filed or the time for such filing has expired, the Parties and their counsel shall meet, either in person or by telephone conference call, with the Tribunal at which time the Tribunal, having due 
regard to the submissions of the Parties, shall determine the issues upon which the Parties are in disagreement (the "Disputed Issues"), the extent of any discoveries to be permitted, the granting of any interim orders of relief that [may] have been applied for in the Pleadings, scheduling of the balance of the arbitration including [any] oral hearing, and such other matters as either the Claimant or any Respondent has raised.

\section{Section 0.11 Evidence Gathering and Discovery:}

(a) Where a Party on notice to the Tribunal and the other Parties alleges that relevant evidence is or may be in the possession of any other Party, and can satisfy the Tribunal that there is a conflict, disagreement or uncertainty on important evidentiary matters that Party may demand that the Tribunal require any other Party to:

(i) respond in writing to information requests under oath or affirmation;

(ii) produce further documents including documents that are either adverse in interest to the producing Party or confidential (but not documents in respect of which such Party may validly claim privilege pursuant to subsection $0.16(\mathrm{~b})$ );

(iii) produce witnesses including experts for attendance at a pre-hearing oral examination under oath or affirmation.

(b) Where a Party on notice to the Tribunal and the other Parties alleges that a third party has relevant and important evidence, the Tribunal may demand production of that evidence in such form and on such terms as the Tribunal may prescribe which will fairly protect the interests of all Parties. ${ }^{135}$

(c) All procedures commenced pursuant to subsections (a) and (b) of this Section shall be completed within [set number] days of the [receipt of] the initial demand or request [by the Party to whom such initial demand or request was made].

(d) Any evidence obtained by a Party adverse in interest in response to a demand or request under this Section may be submitted to, and relied upon by the Tribunal as prima facie proof of its contents unless an opposing Party raises a reasonable doubt about the reliability of such evidence, in which case the Tribunal may determine the admissibility, weight, relevance and materiality of such evidence.

(e) Where there is a conflict in the expert(s) reports or evidence on an important matter in the Dispute, the Tribunal may retain a neutral, independent and impartial expert qualified in the subject matter. Such appointment shall be made pursuant to the Arbitration Rules ${ }^{136}$ and in consultation with the Parties on the selection of, qualifications of, and issues to be submitted to such expert. The Parties shall receive clause. 
all documents submitted by such expert to the Tribunal, and shall have an opportunity to examine, and/or to offer written [or oral] rebuttal of any evidence presented to the Tribunal by such expert.

(f) The Tribunal may determine the admissibility, weight, relevance and materiality of any evidence.

\section{Section 0.12 Final Prehearing Conference:}

(a) As soon as practicable after its appointment but no later than [set number] days after conclusion of the evidence gathering and discovery stage in Section 0.11 of this Article, and in any event no later than [set number] days after the last of the Pleadings has been filed or the time for such filing has expired, the Tribunal shall arrange a conference whereby it meets with the Parties and their counsel, whether in person or by telephone conference call, at which time the Tribunal, having due regard to the submissions of the Parties, shall address: the granting of any interim orders of relief that on notice may have been applied for after the last Pleading was filed; whether there is to be an oral hearing; scheduling of any witnesses; settlement of facts, issues or other matters; the procedures to govern conduct of any hearing; the reading in of any discovery evidence; the presentation of any other evidence; the substance of any other evidence that was not disclosed in discovery, and the ordering of any discoveries on such evidence; and any other matters as the Tribunal sees fit. The Parties shall also provide the Tribunal with an Agreed Statement of Facts and an Agreed List of Exhibits to be filed within [set number] days after the conclusion of the conference described in this Section, to the extent that the parties have been able to agree upon such matters.

\section{Section 0.13 The Hearing:}

(a) Where there is a conflict, disagreement or uncertainty on evidentiary matters that are, in the opinion of the Tribunal, important and material to the outcome of the arbitration, any Party may demand, or the Tribunal upon its own initiative may order, a hearing at which oral evidence on the important evidentiary matters so identified will be tendered with the other Parties entitled to call rebuttal evidence (if previously disclosed in the Written Evidence) with all sides entitled to cross-examination limited to such important evidentiary matters.

(b) The award issued by the Tribunal shall be based solely on the evidence adduced in the Pleadings, discoveries, any hearing that may be held or pursuant to Section $\mathbf{0 . 1 2}$ and upon the applicable law. ${ }^{137}$

(c) Any oral hearing shall be held in camera and, unless otherwise agreed by all Parties, only their representatives, their counsel, the Tribunal and those persons called the Tribunal has been selected for expertise of the non-legal variety and it is expected that its members will in part determine the issues by using such expertise, this provision may not be appropriate. 
as witnesses may attend. Upon the request of a Party or on its own initiative, the Tribunal may require any witness(es) to retire during the testimony of any other witness(es). ${ }^{138}$

(d) The following rules shall apply to the presentation by the Parties of evidence at a hearing:

(i) each of the Parties may present its evidence through a panel or panels of witnesses or otherwise as it sees fit;

(ii) the testimony of all witnesses shall be under oath or affirmation;

(iii) the Claimant shall present its evidence first, then Respondents shall present their evidence including any rebuttal evidence and finally the Claimant shall present its rebuttal evidence, surrebuttal evidence may be presented with leave of the Tribunal; and

(iv) the order of examination of witnesses shall be examination-in-chief by counsel for the Party, cross-examination by counsel for the other Parties and then re-examination by the Party's own counsel. Members of the Tribunal shall also have the right to examine witnesses.

(e) Following conclusion of the evidence, the Claimant shall present its oral argument which shall be followed by the oral argument of the Respondent, to which the Claimant shall have the right of reply. The Tribunal may, whenever it deems it advisable to do so, order written briefs of argument to be submitted by the Parties, prior to and in addition to [or in lieu of] their oral arguments. The Tribunal shall specify whether any written briefs of argument are to be submitted [set number] days prior to, or within [set number] days after, oral argument, but in no event may such briefs exceed [maximum] pages. [In the event that both written briefs of argument and oral argument occur, the Parties shall make every reasonable effort to decrease the length of time spent on oral argument.]

\section{Section 0.14 Interim Measures Generally: ${ }^{139}$}

(a) The Tribunal, the Specified Court, or any other court having jurisdiction over any of the Parties or any of their assets may be utilized by any of the Parties to grant interim measures which would normally be granted [under the laws of the jurisdiction of the Specified Court], including but not limited to the detention, preservation and inspection of property, the production and inspection of documents, the discovery of parties, experts and [other] witnesses, the subpoenaing of witnesses and documents, the

This provision is similar to art. 25(4) of the UNCITRAL Arbitration Rules. There is no equivalent provision in the UNCITRAL Model Law.

139 The UNCITRAL Arbitration Rules and the UNCITRAL Model Law provide for the Tribunal to rule on its own jurisdiction, including matters pertaining to the existence or validity of the provisions providing for arbitration. 
granting of interim injunctions, appointment of receivers, the provision of security for costs [and the provision of security for the full amount of the claim]. ${ }^{140}$ Any Party applying for such relief shall endeavour to make such application on notice to the Tribunal and the other Parties unless that Party demonstrates to the Tribunal or any of the aforementioned courts (whichever the case may be) that providing notice would prejudice [cause irreparable damage to] such Party, in which case the Tribunal or any of the aforementioned courts may order such measures on an ex parte application.

\section{Section 0.15 The Award:}

No later than [set number] days following the conclusion of the hearing, the Tribunal shall furnish to all Parties a written statement of its decision which shall include:

(i) the findings of fact on which it based its decision; and

(ii) reasons for that decision. ${ }^{141}$

The decision of the Tribunal shall be final and binding on the parties as to the questions submitted to arbitration. [There shall be no appeal from or judicial review of such decision]. ${ }^{142}$ The decision may be appealed to or reviewed by the Specified Court on:

(i) any of the grounds set forth in the Arbitration Rules; ${ }^{143}$ or

(ii) the ground that the Tribunal erred in law in making the award.

\section{Section 0.16 Confidentiality of Information:}

(a) All Parties and each of the Arbitrators shall maintain in confidence the written decision of the Tribunal, all documents and other materials and all information obtained from any of the Parties in this arbitration and, further, shall not use the same, or allow

Parties may wish to consider taking this provision even further, allowing the Tribunal to sanction any Party failing to post such security. An example of such a sanction would be the ability to render summary judgment. Such provisions would vest the Tribunal and the courts with the ability to enforce any awards ultimately obtained.

Reasons are likely only needed in complex arbitrations involving substantial amounts of money. In simple, straightforward cases, such a provision should be dispensed with, as it only serves to increase the likelihood that a party will attempt to challenge the decision based upon an argument that the reasons were not legally sufficient.

Exclusions of judicial review may not be looked upon favourably by the courts of all jurisdictions. The first item in this clause may be characterized as a matter which falls within the scope of judicial review, and would likely be difficult to exclude.

The grounds provided for in the Model Law are discussed in Part VI. Parties using the UNCITRAL Arbitration Rules rather than the UNCITRAL Model Law should be aware that although the Arbitration Rules do not contain a similar provision, international conventions, such as the New York Convention, inay stipulate that similar circumstances constitute grounds for refusing recognition or enforcement. 
the same to be used, for any purpose collateral to the arbitration. The Parties shall be responsible for ensuring that their officers, employees, representatives and consultants comply with the obligation of confidentiality herein.

(b) No Party shall refuse to produce any relevant document on grounds of confidentiality alone, provided that a Party may withhold documents if the rules of privilege applied by the laws of [jurisdiction of the Specified Court] would result in such document being privileged in legal proceedings conducted in [jurisdiction of the Specified Court]. ${ }^{144}$

\section{Section 0.17 Time Limitations:}

Although the time limitations specified in this Article may be abridged or enlarged, all arbitration proceedings conducted pursuant to this Article shall be concluded within [set number] days from service of the notice of arbitration referred to in subsection $0.9(a){ }^{145}$

\section{Section 0.18 Interest:}

The Tribunal has the same power with respect to awarding pre- and post-award interest as the Specified Court has under the laws of its jurisdiction pertaining to such matters. ${ }^{146}$

\section{Section 0.19 Costs:}

(a) All Parties shall contribute equally to the fees and expenses of the Tribunal and the administrative costs associated with a hearing including the cost of the hearing room.

(b) Except as described in subsection 0.19(a), each Party shall bear its own costs associated with the arbitration. ${ }^{147}$

In certain cases, the parties may wish to provide that any party withholding relevant information, failing to provide a full response to a request for documents, or failing to truthfully answer questions presented under oath, may be sanctioned by the Tribunal for contempt. [However, the law at least in Canada on this point is not entirely clear, as such sanctions may be solely within the jurisdiction of superior courts of record].

Parties may also wish to consider providing for suspension of any limitation periods during arbitration proceedings. An interesting question is whether such an agreement would be legally enforceable. In any event, such provisions generally serve to protract the dispute. If no such provision is included, the claimant should keep limitation dates in mind and if necessary file a statement of claim simultaneously with the notice of arbitration.

It is important that the drafter be familiar with not only the law of the place of arbitration, but also the laws of the jurisdictions in which enforcement of the award will be sought. Refer to the discussion in Part VI regarding the variety of national law approaches to the question of interest.

147 The UNICTRAL Model Law, arts. 38-40 provide for costs generally following the result with the Arbitrators having a right of apportionment in circumstances where they consider that appropriate. 


\section{Section 0.20 No Punitive/ Exemplary Damages:}

The Tribunal shall not award punitive or exemplary damages. [or consequential damages].

\section{Section 0.21 Independent Agreement:}

The Parties, in consideration of their mutual covenants to submit Disputes to arbitration, agree that if the Agreement into which this Article is incorporated is in whole or in part, invalid, void, voided, illegal or otherwise unenforceable, this Article constitutes a separate agreement among the Parties and the Tribunal is empowered to rule on its own jurisdiction and upon any matters relating to whether the remainder of this Agreement is, or ever was, valid and subsisting. ${ }^{148}$

\section{Section 0.22 Waiver of Immunity:}

(a) All Parties irrevocably consent to and waive(s) any objection which it may now or hereafter have to the laying of venue of any proceeding relating to enforcement of the arbitration provisions of this Agreement or any award thereunder brought in the Specified Court and further irrevocably waives, to the fullest extent it may effectively do so, the defense of an inconvenient forum to the maintenance of any such proceeding in the Specified Court.

(b) To the extent that a Party or any of its revenues, assets or properties shall be entitled, with respect to any proceeding relating to enforcement of the arbitration provisions of this Agreement or any award thereunder at any time brought against such Party or any of its revenues, assets or properties, to any sovereign or other immunity from suit, from jurisdiction, from attachment prior to judgment or from any other legal or judicial process or remedy, and to the extent that in any jurisdiction there shall be attributed such an immunity, such Party irrevocably agrees not to claim and irrevocably waives such immunity to the fullest extent permitted by the laws of such jurisdiction (including, without limitation, [specify legislation]). ${ }^{149}$ 